\title{
Volcanic Geoheritage and Geotourism Perspectives in Hungary: a Case of an UNESCO World Heritage Site, Tokaj Wine Region Historic Cultural Landscape, Hungary
}

\author{
János Szepesi ${ }^{1}$ - Szabolcs Harangi ${ }^{1}$ - Zsuzsanna Ésik ${ }^{2}$ Tibor József Novák ${ }^{3}$ • \\ Réka Lukács ${ }^{1}$ - Ildikó Soós ${ }^{1}$
}

Received: 12 March 2016 / Accepted: 28 October 2016

(C) The European Association for Conservation of the Geological Heritage 2016

\begin{abstract}
In protected areas (e.g. geoparks, UNESCO sites), the identification of the different aspects of geoheritage site values is part of a holistic concept of protection, education and sustainable development. In the past years, significant progress has been achieved in the volcano tourism in Hungary as shown by the acceptance of two geoparks as members of Global Geoparks Network. They are the BakonyBalaton Geopark and the Novohrad-Nograd Geopark, which involves also the old village of Hollókö UNESCO cultural heritage site. These geoparks as well as the recently (2013) opened Kemenes Volcano Park used primarily the volcanological natural values in their application, and these play still an important role to attract the visitors. The Tokaj Wine Region (TWR) Historic Cultural Landscape (inscribed on the World Heritage List in 2002 as a cultural site) is also characterized by high geodiversity due to complex volcanic settings (andesite-dacite composite cones, silicic pyroclastites, lava domes, hydrothermal activity) and specialized viticultural land use of
\end{abstract}

János Szepesi

szepeja@gmail.com

Szabolcs Harangi

szabolcs.harangi@geology.elte.hu

Zsuzsanna Ésik

geozsuzsi@gmail.com

Tibor József Novák

novak.tibor@science.unideb.hu

1 MTA-ELTE Volcanology Research Group, Pázmány Péter Sétány 1/c, Budapest H-1117, Hungary

2 Department of Mineralogy And Geology, University of Debrecen, Egyetem Tér 1, Debrecen H-4010, Hungary

3 Department of Landscape Protection and Environmental Geography, University of Debrecen, Egyetem Tér 1, Debrecen H-4010, Hungary the cultural landscape. While the area of the Bakony-Balaton Geopark is situated in a well-known region and has a long tradition in tourism with a lot of innovation, the Tokaj wine region needs a significant effort to introduce their volcanic geoheritage values into the tourism market. The systematic inventory and assessment of the geoheritage elements are essential steps in different scales of geoconservation and establishment of the priorities in site management. This inventory work emphasizes the relationship between the sites at different scales and highlights the interaction between eroded volcanic relief and human activity. The inventory classifies the objects in two main geosite categories: (a) volcanic edifices resulting from denudation and inversion of the relief and (b) geodiversity sites connected to land use traditions of the cultural landscape. The assessment evaluates the scientific, cultural/historical, aesthetic and socio-economic values and helps to define priorities in site management. The recently suggested $900 \mathrm{~km}$ long, crossHungary volcano route starts at the TWR and involves additional 50 planned stations all along the country. They represent various volcanological phenomena from silicic ignimbrite sheets through andesitic stratocones to basaltic volcanic fields. These meet significant historic, cultural, gastronomic tourism attractions to support the promotion of volcanic geoheritage.

Keywords Volcanic geoheritage · UNESCO cultural

heritage $\cdot$ Geosite inventory and assessment - Geotourism .

Thematic route

\section{Introduction}

Volcanic landscapes are increasingly recognized as areas, which require protection and geoconservation as having unique geoscientific values and offering ideal sites to enhance tourism (Joyce 2009; Erfurt-Cooper and Cooper 2010; Moufti and 
Németh 2013; Erfurt-Cooper 2014; Moufti et al. 2014). Presently, annually, over 150 million people are visiting volcanic areas worldwide, demonstrating the touristic potential of such geosites (Erfurt-Cooper 2011). Spectacular volcanic features define unique geoheritage, and the link between geological knowledge and tourist industry led to the formation of the geopark concept in Germany in the late 1990s (Gerolstein, Vulkaneifel, Frey et al. 2006) The geoparks are well-defined territories where sites and landscapes of international geological significance are managed with a holistic concept of protection, education and sustainable development (Brilha 2016, http://www.unesco.org). The UNESCO Global Geopark Network (GGN) uses its geological heritage, in connection with all other aspects of the area's natural and cultural heritage, to enhance awareness and understanding of key issues facing society (http://www.unesco.org, www.globalgeopark.org, Frey et al. 2006). The visitor centres with interactive exhibition could greatly help to attract people how volcanoes work and could have a key role to enhance tourism and transfer money to local economy (e.g. Volcania in France; Cayla 2014).

The IAVCEI (International Association of Volcanology and Chemistry of the Earth's Interior) Commission on Volcano Geoheritage and Protected Volcanic Landscapes (VGPL) was established in 2015 to help delivering the scientific knowledge to the management of protected volcanic areas and identifying and communicating the scientific and geotouristic values of volcanic areas. Volcano tourism is getting to involve visiting not only active volcanoes but dormant and extinct volcanic regions, as well (Erfurt-Cooper 2014). The ancient, eroded volcanic regions give a different view of the volcanic successions (Cas and Wright 1987) where the primary landforms have been transformed by denudation and tectonic processes. These terrains represent root regions of degraded volcanic cones (e.g. Edinburgh World Heritage City 2011) or exposition of spectacular intrusive forms (e.g. Devil's Tower, WY, USA, Wood 2009). The associated cultural landscapes (Pingvellir National Park, Iceland, Pingvellir Commission 2004), the renewable geothermal resources and the spa/wellness tourism (Erfurt-Cooper and Cooper 2010) could help to raise and combine the different touristic motivation and interest. Geotourism has been recognized as a discipline within the German geoscientific community since the late 1990s (Frey et al. 2006) which promotes tourism to geosites and enhances conservation of geodiversity to understand earth science issues through appreciation and learning (Newsome and Dowling 2010). In this concept, the geological heritage (or geoheritage) and the geosites refer to particular types and locality of geodiversity elements that have acquired scientific, cultural/historical and or socio-economic value (Reynard et al. 2007, 2015; Brilha 2016). The selection of the sites for geotourism purposes requires careful inventory in the first step (Lima et al. 2010; Feuilliet and Sourp 2011). The further assessment could be carried out from several perspectives with an emphasis on scientific, cultural and economic parameters of the sites. The results can serve as a basis to the identification of geotourism potential and designation of management priorities (Kubalikova 2013).

The Carpathian-Pannonian region (CPR) offers a good opportunity to take part in the global volcano tourism since it has a wide range of volcanic heritages formed mostly for the last 20 Myr (Harangi 2014). Recognizing their scientific values, two geoparks (Novohrad-Nógrád Geopark in 2010, BakonyBalaton Geopark 2012) and a volcano park (Kemenes Volcano Park in 2013) have been established there in the last years and further efforts have been made to increase the geotouristic potential of these sites. However, systematic inventorying of geosites is still lacking what would be necessary to establish a geoconservation strategy and to promote them for touristic purposes. Nevertheless, there is still no standardized method in inventorying geological heritage and quantifying geodiversity (Wimbledon et al. 1995, 1999; Brilha 2002, 2015; Lima et al. 2010; Ruban 2010; Henriques et al. 2011; Fuertes-Gutierrez and Fernandez-Martinez 2012; Bruno et al. 2014; Neches 2016), which promotes often debate about the ranking and valuing geosites and geoparks (e.g. Ruban 2016; Warowna et al. 2016). Here, we provide a brief summary about the volcano touristic potential of Hungary with the recently proposed plan of the Pannonian Volcano Route (PVR; Harangi et al. 2015), which would start in the Tokaj Mts., north-east part of the CPR. The Tokaj Mts. is known as the area of the Tokaj wine region, a historic cultural landscape inscribed within the World Heritage List (World Heritage Committee 2002). On the other hand, geoheritage does not form an integral part of the destination brand. Thus, it is a challenging task how geological heritage can be introduced into the tourism market worldwide (Edinburgh World Heritage City 2011; Pingvellir Commission 2004; Hroncek 2015). It is important here, since Tokaj Mts. is one of the regions, where the actual link between the soil formed on volcanic rocks and their influence on the wine varieties has been already proved; hence, the scientific info is available to be incorporated to the geotouristic programs. However, in order to integrate the geoheritage phenomena as touristic attraction, first, it is necessary to conduct a careful inventory and assessment of the geological and geomorphological values integrating them with the mining heritage, manufactory traditions and viticulture related objects. This first systematic evaluation of geosites in addition to a few further localities along the planned volcano route could help to the realization of the plan.

\section{Volcano Tourism Perspectives in the Carpathian-Pannonian Region}

The Carpathian-Pannonian region (CPR, Fig. 1) in easterncentral Europe has got a long history of volcanism closely associated with the tectonic evolution and formation of the 
Geoheritage

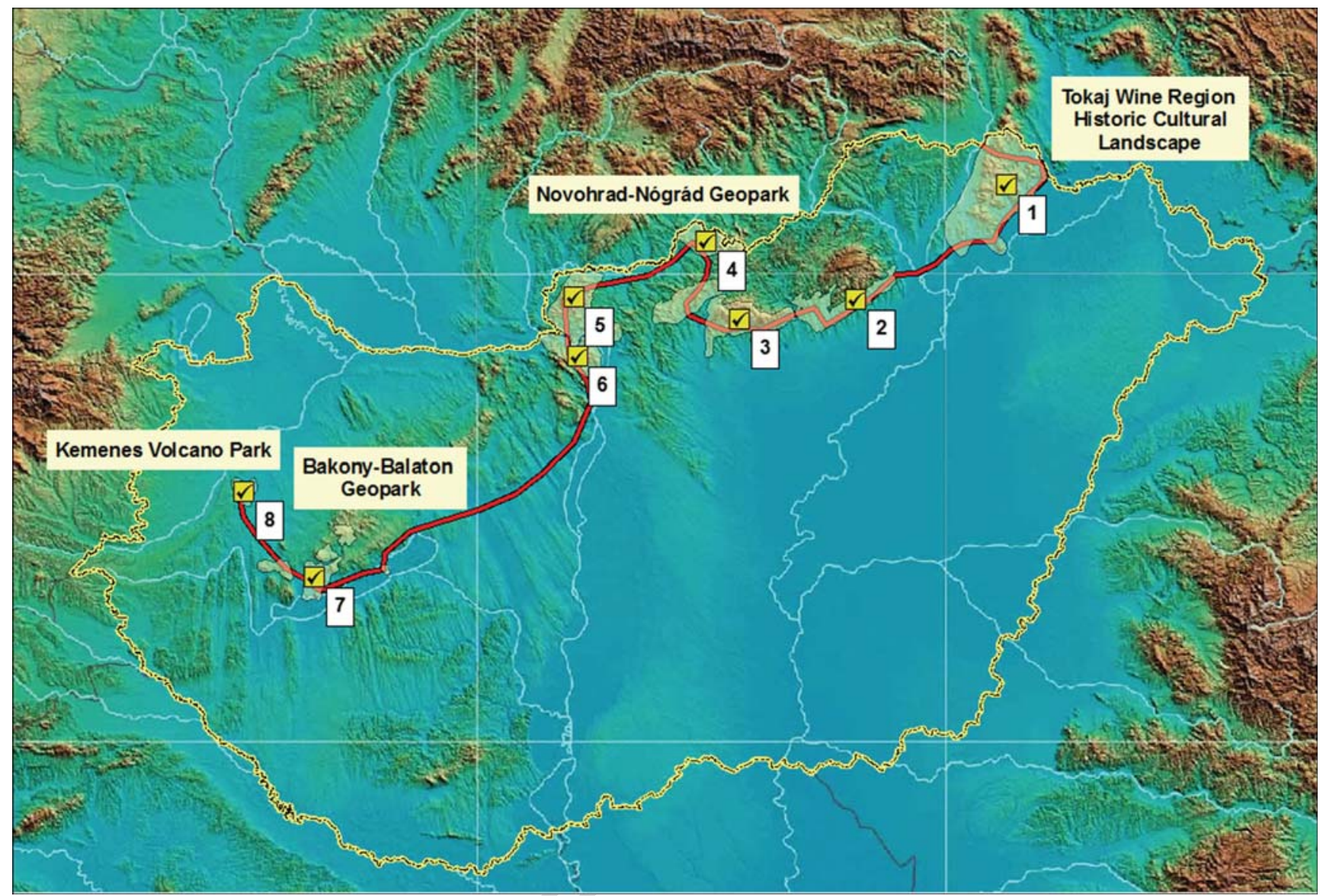

Fig. 1 The Carpathian-Pannonian region and a suggested volcano route with selected stops of volcanic spectacles. 1 Tokaj Mountains (silicic ignimbrites and lava domes, andesite-dacite composite volcanoes), 2 Bükkalja Volcanic Field (silicic ignimbites), 3 Mátra-Cserehát Mountains (andesite composite volcanoes), 4 Novohrad-Nógrád Geopark (silicic ignimbrites, young basalt shield volcanoes), 5
Pannonian basin (Horváth et al. 2006). The Pannonian basin was formed and evolved between the uprising orogenic chains of the Alps, Dinarides and Carpathians. It was accompanied by eruption of various magmas (from basalts to rhyolites) forming a wide range of volcanic landforms from monogenetic volcanic fields to polygenetic stratovolcanoes, from maars to ignimbrite fields (Harangi 2001, 2015; Konecny et al. 2002; Martin and Németh 2004a; Seghedi et al. 2004, 2005; Harangi and Lenkey 2007; Lexa et al. 2010; Seghedi and Downes 2011). The extensive volcanism has gradually calmed down and the volcanic landforms have changed considerably, leaving the eroded remnants of the volcanic edifices. However, this transformation provided a unique benefit, i.e. a spectacular insight into the nature and the structure of the inner parts of the volcanoes. Thus, a majority of them can be considered as volcanic landforms resulting from denudation and inversion of relief (Wood 2009). Presently, they form spectacular landscape and provide the history of a very active volcanic history of the region. Furthermore, the volcanic heritage meets cultural and historical heritages and gastronomic and winery
Börzsöny (andesite-dacite composite volcano and lava domes), 6 Visegrád Mountains (andesite-dacite composite volcano and lava domes) 7 Bakony-Balaton Geopark (younger basalt shield volcanoes, tuff rings, scoria cones) 8 Kemenesalja Volcanic field (remnants of tuff rings, maar, scoria cones). Basemap:http://geophysics.elte. hu/atlas/geodin_atlas.htm

pleasures, making them ideal places for geoconservation and to establish geoparks (Harangi 2014). Similar situation has already been recognized in the nearby area of Styria (EAustria), and this led to the establishment of the Steirisches Vulkanland (Edelsbacher and Koch 2001; Hoenig 2005, www.vulkanland.at), a brand that could successfully increase the touristic potential of the area and enhanced the economic income.

\section{Geoparks and Volcano Park in Hungary}

In the past years, significant progress has been achieved in the volcano tourism in Hungary as shown by the acceptance of two geoparks as member of the European and Global Geoparks Network and the opening of the Kemenes Volcano Park. Both geoparks used primarily the volcanological natural values in their application and these play still an important role to attract the visitors.

The Novohrad-Nógrád Geopark (NNG; http://www. nogradgeopark.eu, Fig. 1) was established in 2010 and is the 
first 'across border' geopark situated in northern Hungary and southern Slovakia. It is rich in volcanic heritage including pumiceous ash-flow (ignimbrite) deposits, submarine and subaerial lava flows, one of Europe's largest coherent lava plateaus, exposed subvolcanic bodies and volcanic vents, maars and diatremes, platy and columnar jointed basalts and andesites including a unique concave-shaped 'andesite-slide', rare almandine garnet in the volcanic rocks and fragments from the upper mantle. All of these are accessible within a restricted, small area $\left(1587 \mathrm{~km}^{2}\right)$, what makes it without doubt an excellent place to gain a unique insight into volcanologic processes. One of the main attractions is the geosite in Ipolytarnóc awarded by the European Diploma of Protected Areas (Fig. 2a). This locality became famous when a petrified tree of $100 \mathrm{~m}$ length and a circumference of eight metres was discovered (Tuzson 1901). This makes it probably one of the largest petrified pine trees in the world. In addition, large number of footprints and remnants of rich mid-Miocene flora were found in a sandstone buried and preserved by a hot pumiceous pyroclastic flow deposit (Kordos 1985; Hably 1985; Pálfy et al. 2007). The newly reshaped visitor centre offers an interesting outline of this geological heritage and includes a movie theatre with world-class $3 \mathrm{D}$ animation, which introduces visitors to the prehistoric past.

The Bakony-Balaton Geopark (BBG; http://www. geopark.hu, Fig. 1) has an extent of $3244 \mathrm{~km}^{2}$ and comprises 171 different geological formations of various ages. It became the member of the European Geopark Network in 2012 and was included into the UNESCO Global Geoparks Network in 2015. One of the main geologic attractions of this area is the spectacular basalt volcanic field formed from 7.9 to $2.6 \mathrm{Ma}$ (Martin and Németh 2004a). It involves maars, tuff rings and scoria cones as well as shield volcanic landforms. However, as a result of strong post-volcanic erosion, only basalt-capped volcanic hills (butte) have remained, providing the unique landscape such as seen in the Tapolca basin (Fig. 2b Gadányi 2015). The volcanoes offer unique insight into the inner structure of the edifices involving the diatreme facies as well as the various types of phreatomagmatic and magmatic products and columnar jointed lava lake and lava flow rocks. Combination of the knowledge about the volcanism and the cultural heritage of the area is nicely presented in two visitor centres, at Tihany (Levander house) and Hegyestü (Harangi 2014, www.geopark.hu).

The two geoparks have, however, different situation backgrounds. While the area of the BBG is situated in a wellknown region and has a long tradition in tourism with a lot of innovation, the NNG is a multi-factored disadvantage, peripheral region as seen in the regional competitiveness data (e.g. total income from accommodation fee per capita, Bujdosó and Pénzes 2012; Pénzes 2013). It is very hard to find a relationship between geopark establishment and the number of visitors and their night stays in accommodation facilities in the area (Kršák et al. 2015). The more difficult access has less touristic experience and needs a significant effort to introduce their touristic values into the market The experience from the past years is that existence of unique geological and volcanological values is not enough to get a success, but a strong support from the local community is necessary. Furthermore, motivated and enthusiastic people are needed, who understand the geopark concept and can maintain and manage the geopark. The popular training courses for local people to become geopark guides in the BBG are a good example how the geopark can be maintained active, whereas in the NNG, annually, organized interactive volcano show during the Geopark week and wide selection of geological and cultural events help people to know more about the geopark philosophy.

The first volcano park (Kemenes Volcano Park; http:/www.kemenesvulkanpark.hu, Fig. 1) in eastern-central Europe was opened at Celldömölk in western Hungary, close to the borders of Croatia, Slovenia, Austria and Slovakia in 2013. It consists of an open-air volcano playground and volcano path into the $5.5 \mathrm{Ma}$ intensively quarried basaltic Ság volcano (Harangi and Harangi 1995; Martin and Németh 2004 b). The volcano path (Fig. 2c) with 12 stops reveals the diverse eruption history (phreatomagmatic, strombolian and hawaiian as well as effusive volcanic products). At the foot of the Ság hill, an interactive exhibition was designed in a unique visitor centre. The exhibition provides an interesting tour in the world of volcanoes involving the formation of various volcanic fields of the Carpathian-Pannonian region.

\section{A Plan for an Across-Country Volcano Route}

Volcanic and geological heritage could be a driving role to open a new way in the tourism and promotes a recovery of economy in otherwise underdeveloped regions (e.g. Iceland Geoparks, Ólafsdóttir and Dowling 2014; Banska Stiavnica mining heritage, Slovakia, Herčko et al. 2014; Leon Province, Spain, Fuertes-Gutierrez and Fernandez-Martinez 2010). This can be achieved by a combination of delivering scientific information with entertainment. In the last year, we proposed a new way to highlight the value of volcanic regions of Hungary (Harangi et al. 2015). The idea is based on the success of thematic trails, such as the popular National Blue Trail (established in 1938) in Hungary, which was the first long distance walking route not only in Hungary but in the whole Europe (Horváth and Lóczy 2015). This helps people to

Fig. 2 Stops on the volcano route. a Visitor centre of Nature Reserve Ipolytarnóc Fossils geosites, Nógrád-Novohrad geopark (still qualifying for UNESCO World Heritage site). b The beautiful volcanic landscape of the Tapolca basin in the Bakony-Balaton Geopark: eroded remnants of various basaltic volcanoes. $\mathbf{c}$ On the volcano path of Ság Hill, involving all principal types of basaltic volcanic activity. Photos by Szabolcs Harangi 


\section{AUTHOR'S PROOF!}

Geoheritage

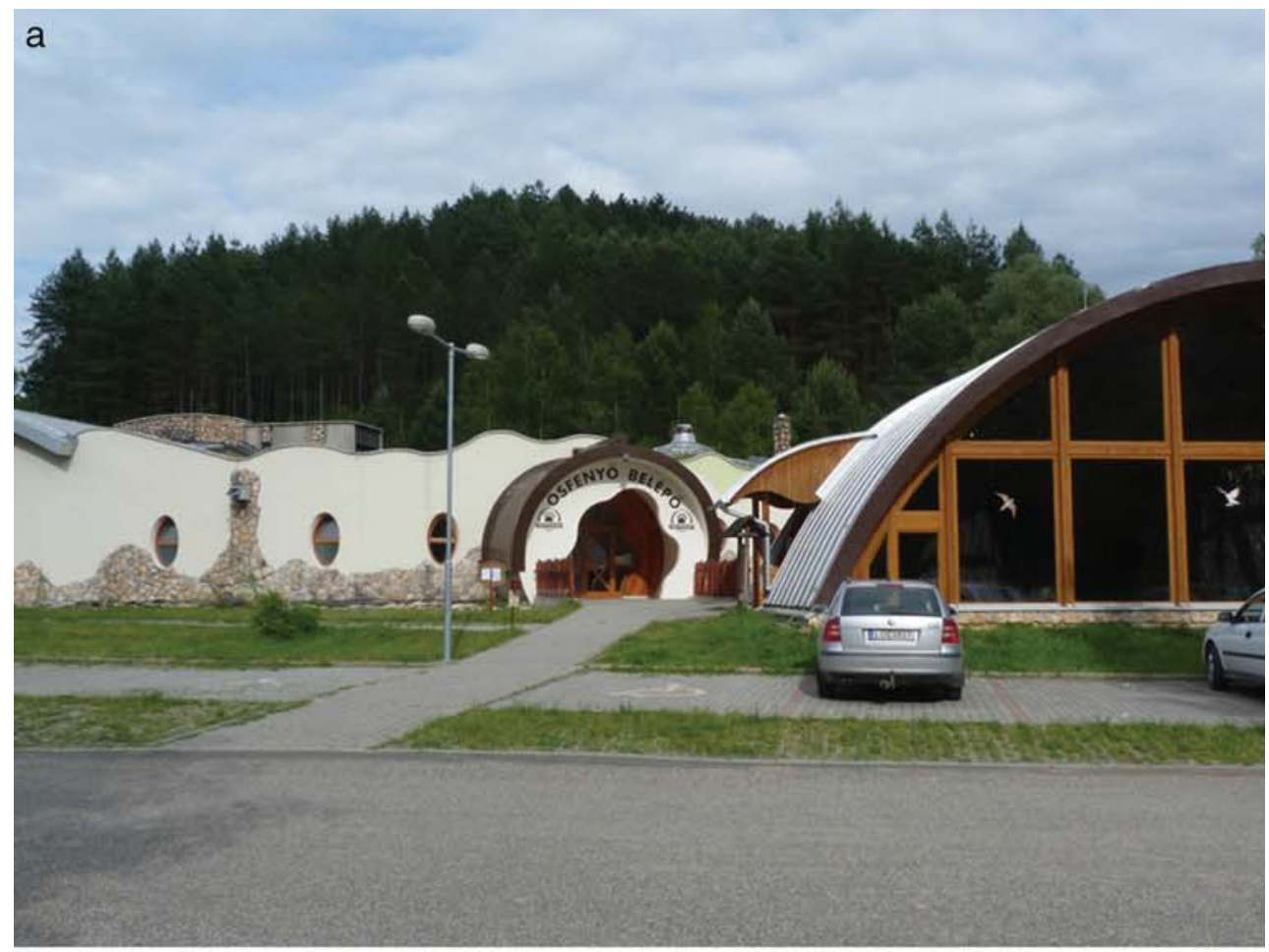

b

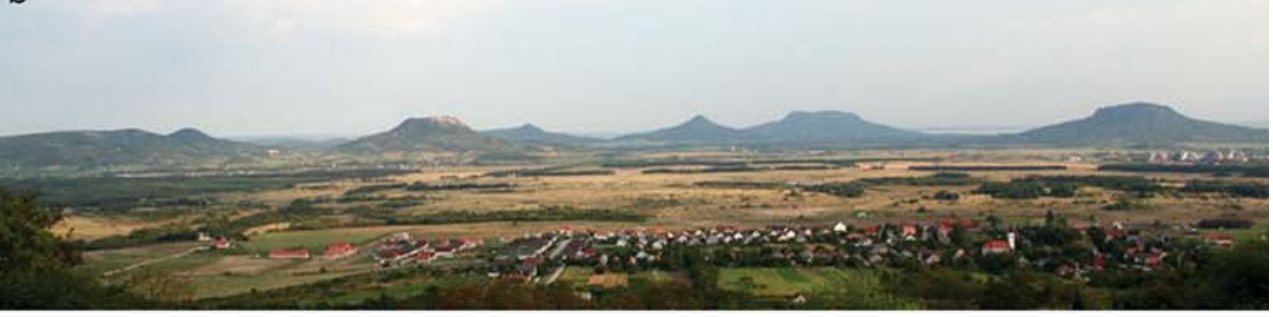

c

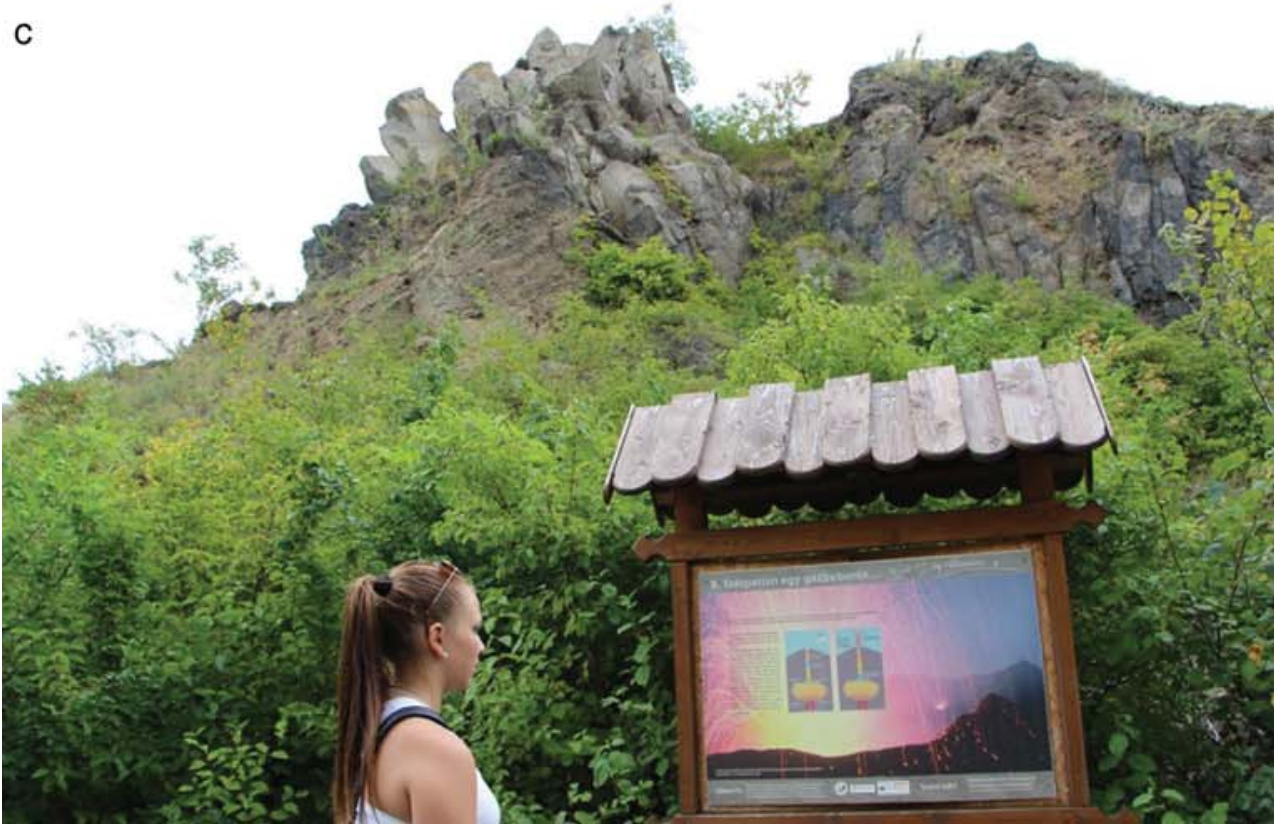


recognize the importance of hiking and to have walks regularly in the nature as well as to accomplish the whole route through the country. The Maria Trail is a pilgrimage across central Europe from Mariazell (Austria) to Csíksomlyó (Şumuleu Ciuc; Romania) that helps people to recognize the religious and cultural heritage during hiking. There is a good example of such thematic trails also in volcanic areas. The Deutsche Vulkanstrasse (German Volcano Route; http://www.deutsche-vulkanstrasse.com) was designed in the Eifel area, Germany, and connects 39 localities to recognize the wonderland of volcanoes. The planned PVR (Fig. 1) in Hungary is about $600 \mathrm{~km}$ long, crosses the whole country from east to west and could be part of an even longer, across-Europe volcano route that would include active and inactive volcanic regions.

The PVR connects the existing geoparks and the volcano park, emphasizes the role of volcanic activity, which formed the landscape of the area over the last $20 \mathrm{Myr}$, and offers additional recreational activity in several subregions. There are over 50 planned key stations, where additional shorter routes help to discover the beauty of the area involving historic, cultural, mining and gastronomic heritage. Furthermore, they cover almost all the main volcanological phenomena. An important task, however, is the transformation of volcanic heritage to touristic value and thus, a systematic inventory of geological heritage is crucial. A case study in the Tokaj wine region, a UNESCO World Heritage Site, is shown in the following chapters and how the first steps in this work were made. This is the area, where the PVR starts and provides a challenging task to investigate how volcanic heritage can be recognized in a historic cultural landscape awarded as a UNESCO World Heritage Site.

\section{Tokaj Wine Region UNESCO World Heritage Site}

Cultural sites are far better represented by the World Heritage Convention (Fig. 3a) than natural ones (802 cultural, 197 natural and 32 mixed sites in 2016). Many of them, however, contain also remarkable volcanic geoheritage values and thus are categorized as mixed sites (Cappadocia, Tongariro National Park), while in other cases, primarily, the cultural aspects are emphasized (e.g. Pingvellir National Park, Iceland, Pompei, Italy; Fujisan, Japan; Banska Stiavnica, Slovakia and Tokaj wine region, Hungary). The Tokaj Wine Region (TWR) Historic Cultural Landscape was the World's first delimited wine region (since 1737) and demonstrates the long tradition of wine production covering 27 settlements and ca 90,000 ha (Fig. 3b). It is famous of the special sweet wines (called 'aszú' in Hungarian or Tokay, worldwide) made from grapes affected by noble rot (Botrytis cinerea), a style of wine which has a long history in this region. The special microclimatic condition in the eroded volcanic slopes and the surrounding wetlands gives an ideal place to cultivate various grapes, primarily Furmint, the most important grape in the production of the Aszú wines. The geology behind the grape production is, however, less known in spite of its importance in viticulture. There are even more potential in the geological heritage, as demonstrated by the high geodiversity values due to its complex geological setting, by the long mining and manufacturing activities and also by the role in the early history of geosciences. The uniqueness of many geomorphological and geological sites has been already recognized and some of them have been already protected (UNESCO convention, national nature conservation area, Natura 2000).

\section{Geology-Geomorphology}

The TWR is the UNESCO World Heritage part of the TokajSlanske Vrchy Mountains which is a north-south trending volcanic chain, extending over $100 \mathrm{~km}$ through the Hungarian-Slovakian border (Fig. 3b). This volcanism was part of the extensive Miocene to Quaternary calc-alkaline andesitic-dacitic volcanic activity of the Carpathian-Pannonian region (Harangi 2001; Konecny et al. 2002; Seghedi et al. 2004, 2005; Harangi and Lenkey 2007; Lexa et al. 2010). The Proterozoic to Mesozoic metamorphic and carbonate basement was subsided and formed a north-south-oriented graben-like structure hosting the volcanic sequences (Molnár et al. 1999; Gyarmati and Szepesi 2007; Zelenka et al. 2012). The available K/Ar radiometric ages (Pécskay et al. 1987, 1989, 1995; Pécskay and Molnár 2002) suggest that this geochemically bimodal, andesitic-rhyolitic volcanism took place between 15 and $10 \mathrm{Ma}$. The mid-Miocene extensional tectonic process was accompanied with marine transgression; thus, the thick Badenian silicic (ash-flow tuffs) and andesitic volcanic formations were accumulated in submarine environment and this was followed by mostly subaerial volcanism. The wide range of eruption styles resulted in primary volcanic landforms such as caldera-related silicic ignimbrite sheets and andesitic-dacitic composite volcanoes as well as dacitic to rhyolitic lava dome extrusions. This kind of volcanic activity could resemble that of the present-state Kagoshima graben

Fig. 3 a Topographic setting of Tokaj Wine Region Historic Cultural Landscapes and UNESCO World Heritage Sites of CarpathianPannonian region with the overall domination of cultural sites (made using public UNESCO database of Arctic online: http://www.arcgis. com/home/webmap/viewer.html). b Main volcanic geomorphotypes of the Tokaj Wine Region Historic Cultural Landscape with vineyards (based on Gyarmati and Szepesi 2007, Karátson 2007, Zelenka et al. 2012). Digital elevation model: SRTM DEM database, vineyards:(CORINE Land Cover 2006 seamless vector data 2016). Volcanic geomorphotypes: a, andesite composite cones and flows, 3 . Nagy Papaj-Fekete Hills, 5. Szokolya-Molyvás group, 6. Hollós-Szár Hills dacite composite cones, 1. Sátor Hills (Sátoraljaújhely), 7. Cigány Hill, 8. Tokaj Hill, silicic pyroclastites and lava dome complexes, 2. Megyer-Király Hills, 4. Szokolya-Nagy páca group, 9. Szerencs caldera 


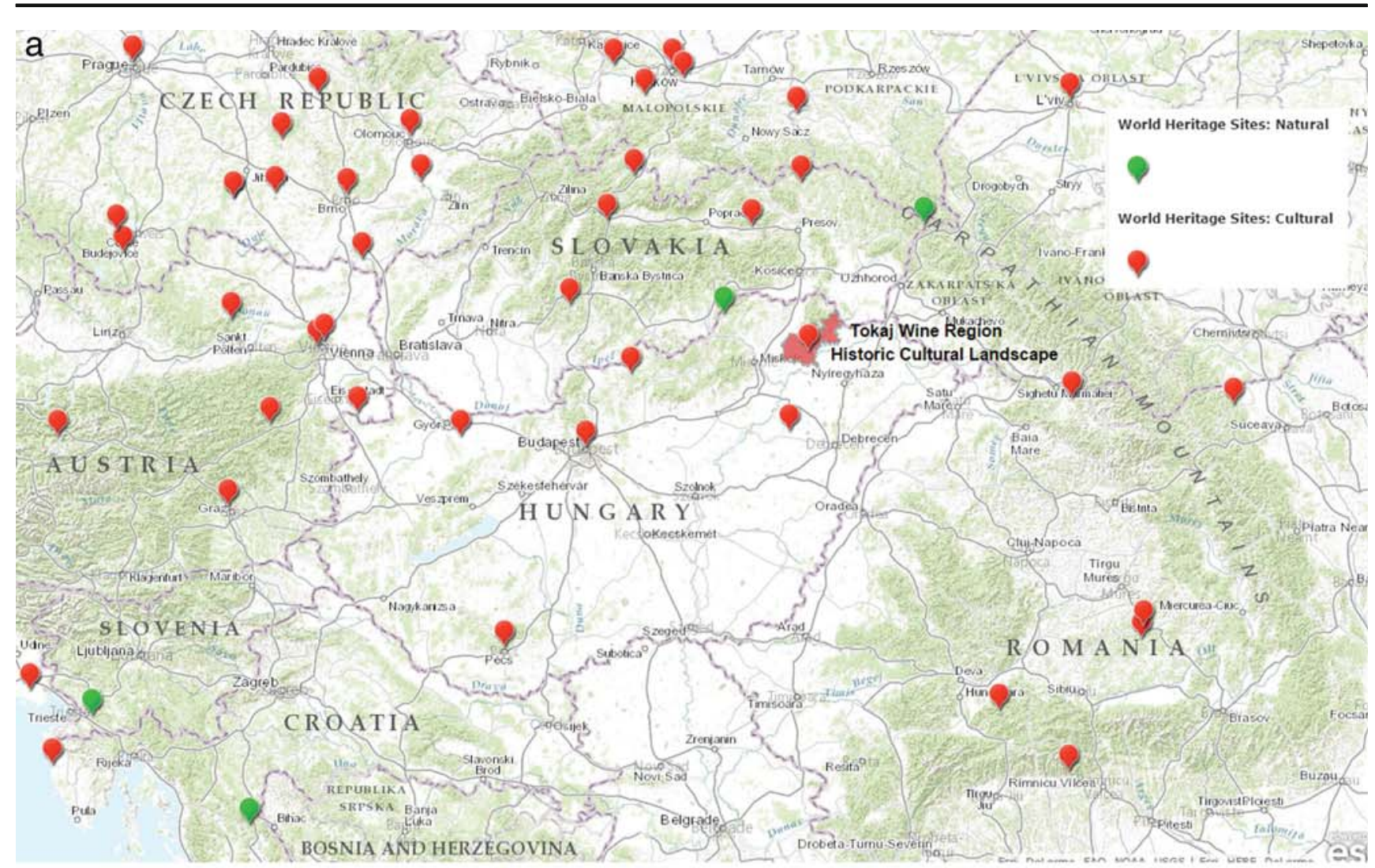

b

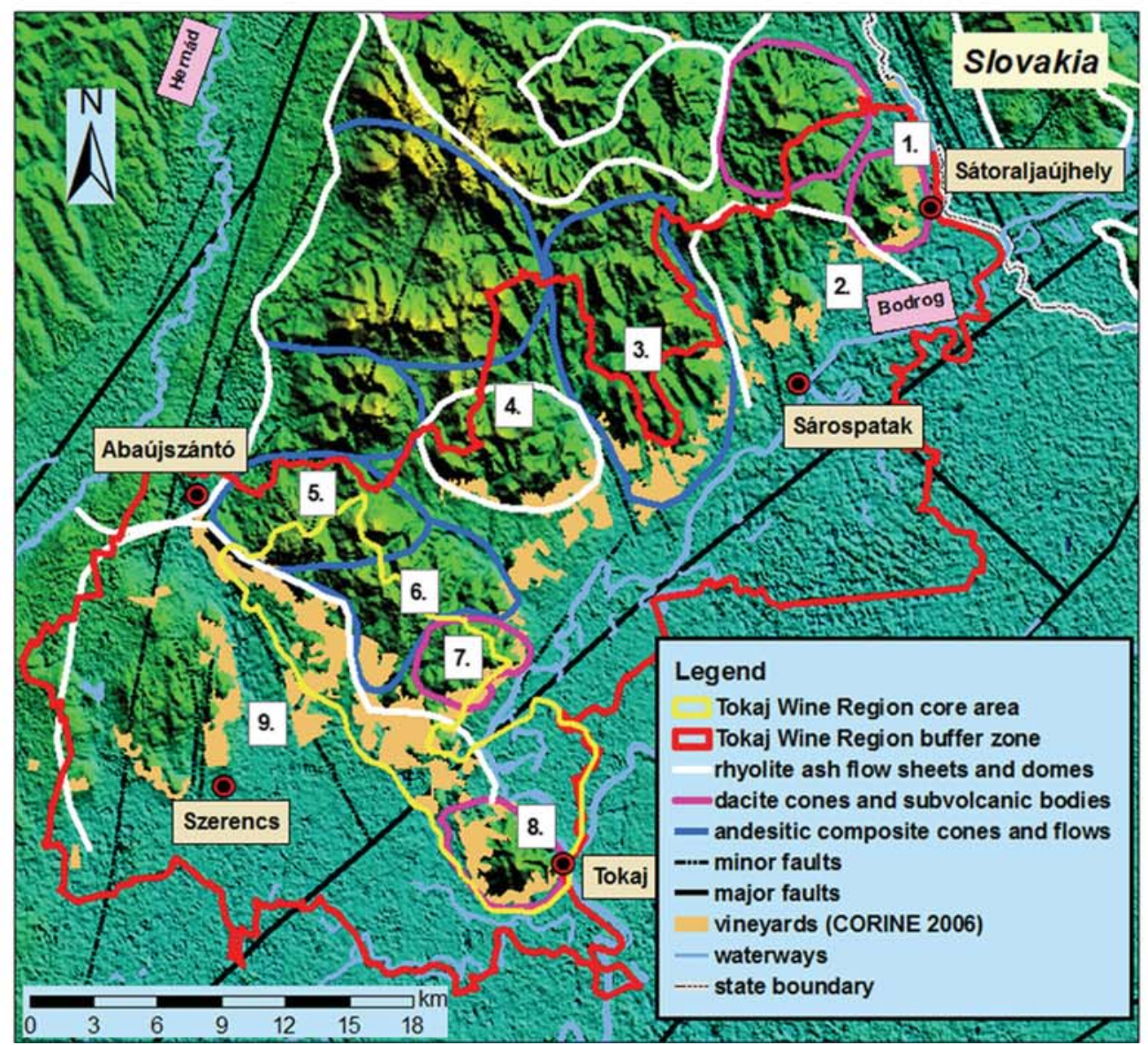


(Aramaki 1984) and Taupo zone (Cole 1990; Wilson et al. 1995). Post-volcanic activity reached a peak in the Sarmatian-Pannonian and resulted in shallow-level lowsulphidation type epithermal ore mineralization (Molnár 1993; Molnár et al. 1999; Bajnóczi et al. 2000). The volcanic landscape has been heavily modified during the subsequent erosion, and even the root zones of the volcanic structures including the mineralized regions (Pécskay and Molnár 2002), necks and the shallow laccolithic intrusions have been exposed. The gentle shape of the basins and valleys and the productive soil on the volcanic basement provided an ideal condition for the human settlements.

Classification of volcanic landforms was initially based on types of activities, magmas and erupted products (Macdonald 1972), whereas more recent classification schemes consider also geomorphologic scale (e.g. constructional vs. erosional origin, mono- vs. polygenetic development), types of activity, and type and volume of magma and erupted material (Thouret 1999, 2004). This latter approach was used by Lexa et al. (2010), who summarized the features of the volcanic edifices of the Carpathian-Pannonian region. Wood (2009) listed the main volcanic landforms based on the volcanic geomorphology review by Thouret (2004) and classified them into five major types in World Heritage properties. In this context, the TWR could belong to the "Volcanic landforms resulting from denudation and inversion of relief', what was represented in the report only by two examples, i.e. the volcanic landscape of Edinburgh and the Aïr and Ténéré Natural Reserves, as inverted small-scale forms and roots of palaeovolcano, respectively. The volcanomorphologic features of the TWR fit well with the subcategory 'eroded cone, eroded pyroclastic flow deposit and sheet' and thus could represent it on the World Heritage volcano list.

\section{Early History of Geosciences and the Role of the TWR}

The significant value of the volcanic geoheritage of the TWR is underlined by the role of its volcanic formation in the history of the earth sciences. Recognition of the volcanic formations in Hungary and particularly in the Tokaj region by the pioneering geologists goes back to the eighteenth century, right in the neptunist-plutonist controversy (Rózsa 2003). Fichtel $(1791,1794)$ described the volcanic origin of the mountains first and defined the widespread perlites as 'volcanic zeolite'. In contrast, Esmark (1798) as a student of the Neptunist school led by A.G. Werner denied the volcanic origin of these rocks based on his tour in Hungary in 1794, claiming that these all are not of volcanic but neptunic origin' and not only the pumices found in the Tokaj Mts but also those coming from Lipari probably all kinds of real pumice are of neptunic origin'. Townson (1797) also studied the peculiar perlites in the Tokaj Mts. and agreed with Fichtel, concerning the origin of this formation, stating by Linneus words where pumice can be found in great quantity, once active volcanoes existed, although, they have been extinct and forgotten for a long time'. He also recognized the great similarity between perlites and the marekanites (obsidian balls aka Apache tears) found in Kamchatka. As regarding the main rock types of the Tokaj Mts, Beudant (1818) followed the Haüy's trachyte terminology to classify the whole eruptive sequence (e.g. trachyte porphyre). The rhyolite term was first used by Richthofen (1860) based on textural and geochemical observations and provided detailed description of the glassy and microcrystalline textural varieties with special attention to the spherulites and lithophysae. Szabó, the most famous petrologists in Hungary in the nineteenth century, proposed that the TWR could be regarded as a rhyolite district, and he recognized the hydration process of the obsidian to form perlite (Szabó 1866). He published a detailed book in four languages with the earliest geological map (Szabó and Török 1867; Fig. 4) of the viticulture and geology of the TWR. All of these historic elements can be build up into the geoeducational possibilities of the TWR geoheritage to show how earth sciences evolved and how the TWR had a role in it.

\section{Mining and Manufactory}

The long period of volcanism and the subsequent hydrothermal activity produced a wide range of potential raw materials and mineral resources. In the TWR, 13 special raw materials (including quartzite, kaolinite, bentonite and perlite) reported from 47 localities (Mátyás 2005, Fig. 5). The exploitation of these materials (rhyolite tuffs and rhyolite, perlite, obsidian lavas) has also a long tradition. At different levels of social and technical development, more and more raw materials were placed in the centre of interest starting from the early Palaeolithic obsidians. The obsidian was derived from the local rhyolitic perlitic lava domes and pyroclastic deposits, and it was used even by Palaeolithic and Neolithic manufactures and was incorporated in the far-reaching trades (T Biró 1984, 2002; Rózsa et al. 2006; Hovorka and Illasova 2010; Mester and Rácz 2010). The major medieval gold-silver mining activity (from the twelfth to nineteenth century), what was the most significant in Europe at that time, occurred mostly outside of TWR (around Telkibánya), but smaller excavation pits and underground adits can be found also within the TWR, north of the Sátor Hill area (Sátoraljaújhely, Rudabányácska). Silicic pyroclastic rocks have the widest areal distribution at the TWR and have been utilized as a natural building stone for several centuries as demonstrated by large numbers of abandoned quarries (e.g. Mád, Sárospatak, Erdőbénye, Fig. 5). Data on ancient quarries were registered in the early domestic geological mining inventory (Schafarzik 1904) and also in recent databases (Atlas of European Millstone quarries, Historic Quarries, Hungarian Mineral Occurences). The silicified zones of the tuffs were particularly suitable for high- 
Geoheritage

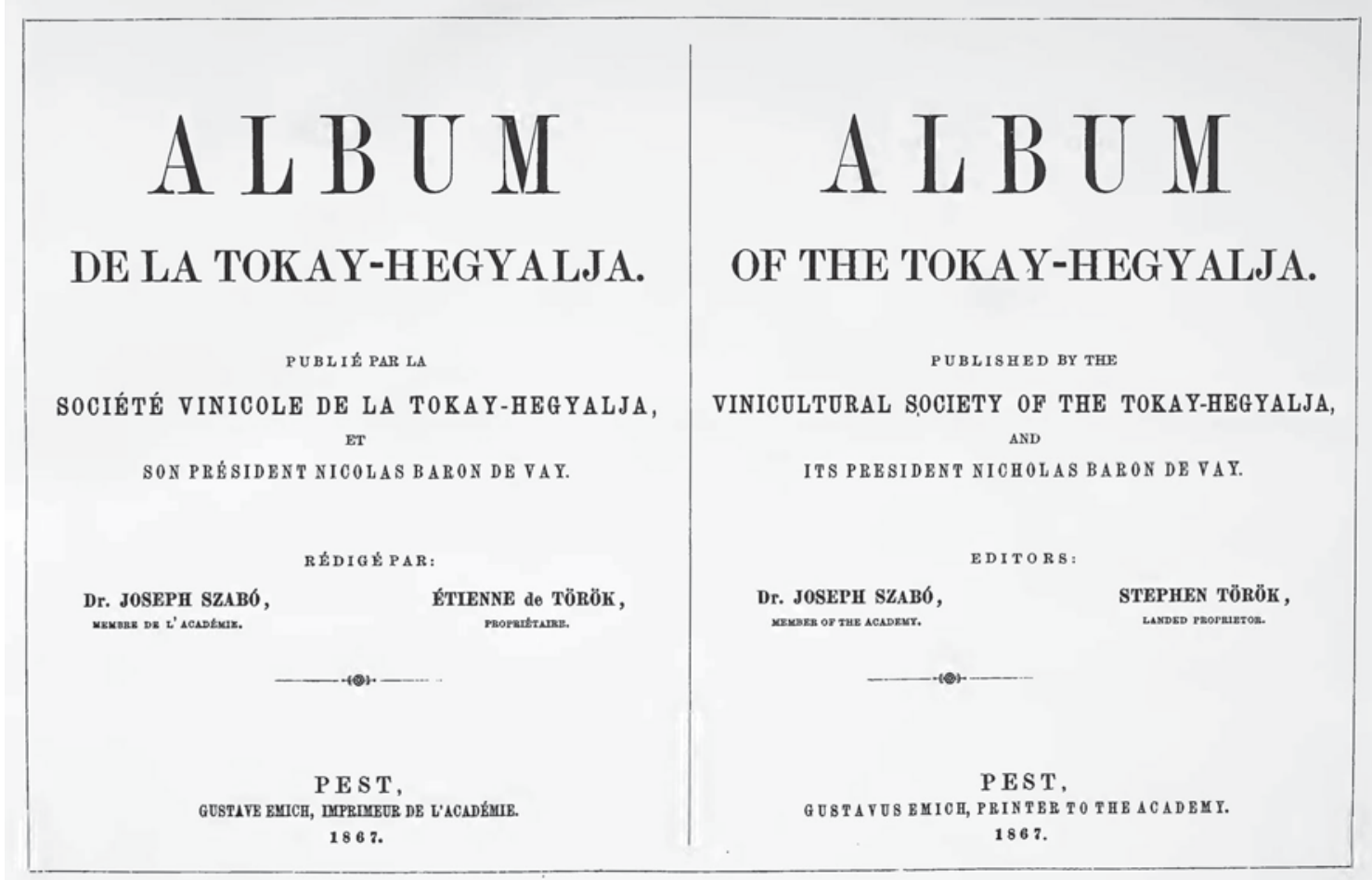

Fig. 4 English and French language cover of Album of Tokay Hegyalja published in four languages (Szabó and Török 1867) containing the first geology and viticulture map of the Tokaj wine region

Fig. 5 Map and classification of quarry sites at Tokaj Wine Region Historic Cultural Landscape as potential geoheritage objects

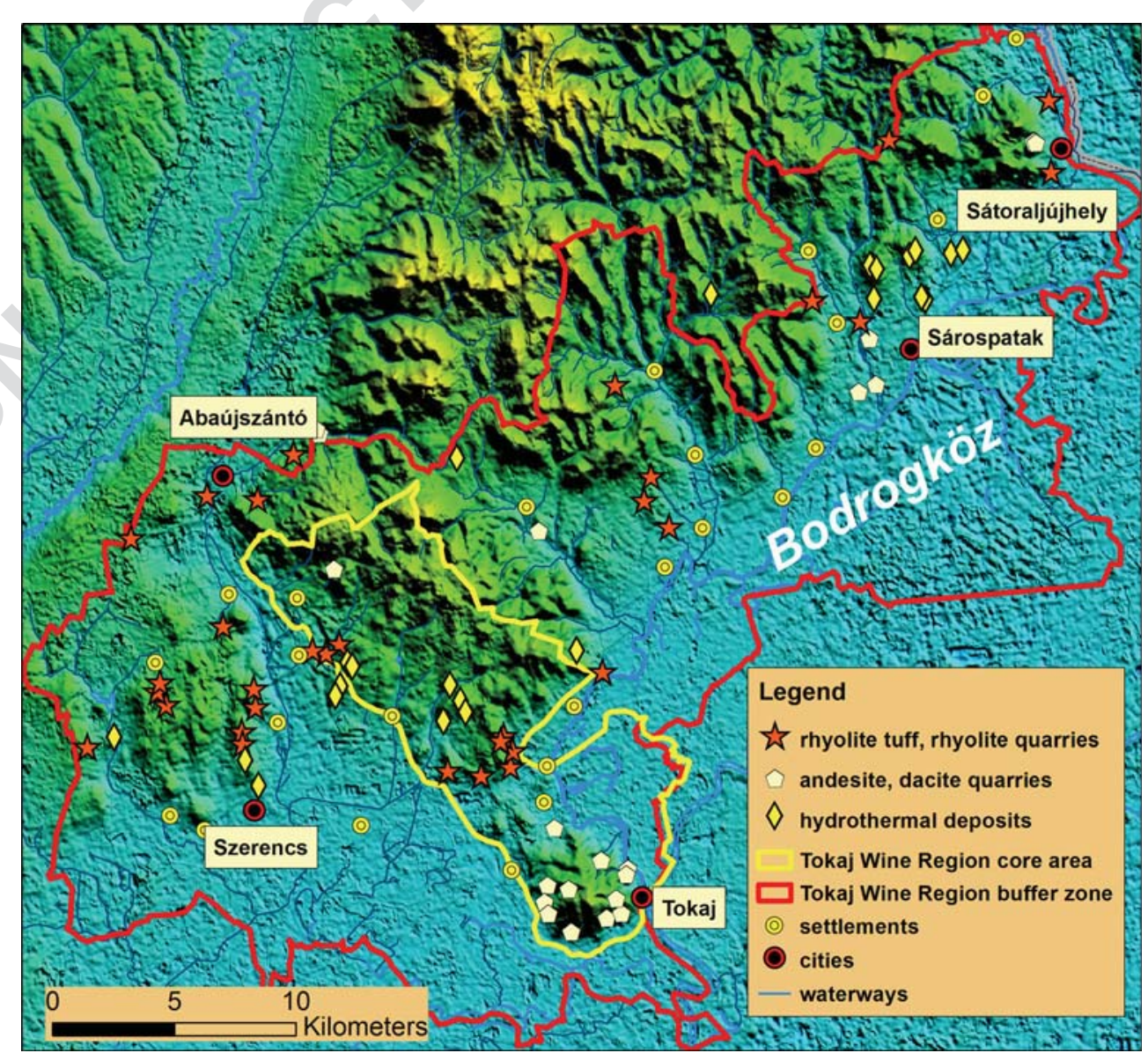


quality millstones (e.g. Megyer Hill, Rátka, Szepesi and Ésik 2015). After the first mentioning from the fifteenth century, quartzite was a popular and precious product over six centuries. The industry was supported by the grindstone demand of gold-silver mining at Telkibánya. The quality of the stones had earned a reputation for Sárospatak, winning the first order medal' of 1862 World Expo in London. The glass industry utilized the loose perlite materials of the silicic lava domes.

This regional industrial activity stimulated the development of clay mineral (kaolinite, bentonite) quarrying and ceramic industry from the 1800 s (Mád, Sárospatak). Pottery, tile stove and pipe factories ( famous black pipe') were also operated (Mátyás 2005). The large variety of dish forms (bowls, plates, jars, food containers, jugs) was widespread in the villages of TWR, Bodrogköz (Fig. 5). The diatomite of Erdőbénye was an important chemical industry material. The connected fossils and leaves imprint enriched many mineral collections. The high-quality andesite and dacite as road building stones have been still quarried (Tokaj Hill, Tállya Sárospatak). In summary, the TWR yields a nice example about the long interaction between society and environment and gives a peculiar connection between geological and mining heritage. This can be integrated into the geoeducational and touristic potential of the area.

\section{Land Use}

Since the viticulture is very sensitive to the changes of the economic environment (Novák et al. 2014), serious changes in extent of vineyards were registered during the last centuries. The beginning goes back supposable to the Iron Age, but it became to the most characteristic land use during the late medieval age (Novák and Incze 2014). The golden age of the Tokaj wine region was in the late seventeenth century and early eighteenth century, when the plantations reached their maximal extent. Decreasing in a vineyard area was first the result of disadvantageous market and export policy of Hungarian wines because it was the highest taxed good within the Habsburg Monarchy in the early nineteenth century (Komlos 1983). Further significant decrease was due to the Phylloxera epidemic between 1885 and 1895 that destroyed almost two third of the plantations (Nyizsalovszki and Fórián 2007). The reconstruction in lack of investment and loss of markets during the first decades of twentieth century was very slow, and the extent of vineyards has never reached the level before the disaster. As a consequence of collectivization and mechanization of the cultivation after the World War II, the vineyards shifted to lower and less steep slopes (Novák and Incze 2014). Nevertheless, 18 land cover categories can be found within the wine region based on the CORINE CLC100 land cover classification (http://www.eea.europa. eu/data-and-maps/data/clc-2006-vector-data-version). The highest extent is reached by croplands, which cover $29 \%$ of the whole area. The second most frequent land cover category is forests, which totally share almost $25 \%$ of the region. Managed and degraded grasslands including succession areas developed after vineyard abandonments cover totally $13 \%$. Vineyards (Fig. 3b) cover more than $10 \%$ of the landscape; all of the other categories share extension less 5\%. In the last decades, between 1989 and 2010, 2173 ha vineyards (29\% of vineyards in 1989) become fallow. During the last 25 years, the slopes with 5-12 and 12-17\%, exposure with S, SE, SW, and W and elevation between 100 and $200 \mathrm{~m}$ were the most preferred topographies in the wine plantation.

\section{Identification of Geosites and Geodiversity Sites}

Geodiversity can be defined basically as the natural range (diversity) of geological (rocks, minerals, fossils), geomorphological (land form, physical processes) and soil features including their assemblages, relationships, properties, interpretations and systems (Gray 2004). There are different concepts and methodologies concerning recognition of geological heritage and inventorying geosites and geodiversity (Reynard et al. 2007, 2015; Gray 2008; Lima et al. 2010; Pereira and Pereira 2010; Wimbledon 2011; Fuertes-Gutierrez and Fernandez-Martinez 2012; Bruno et al. 2014; Brilha 2015). This lead Brilha (2016) to propose a conceptual framework of geodiversity, geoheritage and geoconservation and set a guideline for inventory and assessment of geological and geodiversity sites. Geoheritage involves geosites and geodiversity elements (minerals, fossils, rocks) that have significant scientific value. The selection should be based on four criteria: representativeness, integrity, rarity and the scientific knowledge. The same framework is established for the geomorphological heritage, which involves geomorphosites (Panizza 2001; Pereira and Pereira 2010; Coratza et al. 2011; Reynard et al. 2007, 2015). For a volcanic region, both approach can be applied, i.e. recognizing the morphological elements provided by a volcanic landscape and selecting key localities, which show scientifically valuable volcanic features (e.g. Moufti and Németh 2013; Moufti et al. 2013a, 2013b). Geosites or geomorphosites are defined as the smallest units in the hierarchical system of geoheritage (Reynard et al. 2007, 2015; Pereira and Pereira 2010), although higher units such as geotope (group of geosites; Gonggrijp 1997) and precinct (collective group of geotopes; used, e.g. in the Kanawinka geopark, Australia and in Saudi Arabia; Moufti and Németh 2013; Moufti et al. 2013a) have been also used.

In the TWR, the major aim of the preliminary inventory and assessment was to identify the potential geodiversity objects and raise the geoconservation, the public and the geotouristic sector awareness about these natural attractions. The conceptual framework of geosites and geodiversity sites 
(Brilha 2016) was used as a methodological guideline during the inventory of TWR geoheritage. The volcanological-geomorphological features were clustered together using the precinct concept (Moufti and Németh 2013; Moufti et al. 2013a, 2013b). The volcanic landscape of the TWR can be classified as 'Volcanic landforms resulting from denudation and inversion of relief' based on a geomorphological point of view and can be subdivided into subgroups such as eroded larger composite cones and smaller volcanic bodies based on regional palaeovolcanic reconstructions (Gyarmati and Szepesi 2007; Karátson 2007; Lexa et al. 2010; Zelenka et al. 2012). However, their recognition is not easy and therefore, it seems to be better to define the notable geological sites based on their geological features. In the TWR, we defined three precincts (Table 1, Fig. 3b):

1. Silicic lava dome/flow and pyroclastic deposit precinct

2. Andesite and dacite cones and subvolcanic body Precinct

3. Hydrothermal deposit precinct

Each precinct comprises distinct geotopes and geosites. One of the most prominent geotope is the Tokaj Hill (Fig. 6a), what is a dacitic composite volcanic edifice. It involves various geosites, such as dacitic lava dome rocks showing fine magma mixing features (Szabó 1894; Rózsa 1994) and a fine rhyolite-perlite occurrence.

In the TWR, there is a long tradition of collection of minerals and a wide range of specific mineral species (particularly different types of microcrystalline quartz polymorphs, such as chalcedonies, opals, jaspers, petrified woods) are exhibited in local museums. They can be classified as ex situ geoheritage elements based on Brilha's (2015) system.

In addition to the scientifically important geosites, the traditional land use of cultural landscape generates sites that do not have particular scientific values but significant record of human impact on landscape (terrace wall, wine cellars). Brilha (2015) defined these objects as geodiversity sites. In the TWR, the geology meets culture and history and has a thousand year history of human activity. The utilization of the geodiversity started from obsidian and quartzite tools of the Palaeo and Neolithic cultures (T Biró 1984, 2002; Mester and Rácz 2010) to the characteristic landscape shaping objects of grape cultivation and wine-making traditions. The identified geodiversity attributes involve the various wine cellars, the historic and recent mining activities and the dry-built terrace walls which are also important resources for education and tourism. The scientifically important geoheritage and the geodiversity sites altogether could be involved into the geoconservation strategy of the TWR and can be introduced in the educational and touristic development. Furthermore, they could be important elements to establish a geopark in the TWR and the northern continuation of the Tokaj Mts.

Following the long (ca 5 Myr) volcanism, hydrothermal activity resulted in epithermal mineralization (e.g. gold and silver ores at Rudabányácska) and formed various alteration zones and products. Among these, the TWR is famous of the wide selection of microcrystalline quartz polymorphs (e.g. Erdőhorváti, Tolcsva), diatomite and zeolites (Mád, Erdőbénye area), geyserite cones (Bot-kő, Sárospatak, Árpád Hill) and petrified woods (Megyaszó). Recognition of these geodiversity elements could help the appropriate geoconservation of these localities and incorporation of the local mineral museums into the geoheritage elements. Some of them are already protected (UNESCO convention, national nature conservation area, Natura 2000) which helps in raising public awareness.

One of the specialities of the TWR is the close connection between geology, manufacturing and cultural landscape use. They are classified as various geodiversity sites. Quarrying has a long tradition in the TWR which follows the regional raw material interest and manufacture development through centuries. They are classified (Fig. 5) based on the quarried material, such as andesite-dacite (rubblestone), rhyolite tuffrhyolite (building and decorative stone) and hydrothermal deposits - altered pyroclastites (millstone-Fig. 6e, bentonitemontmorillonite clays) quarries. The mining activity apart from some rubblestone quarries was ceased in the last century due to the economic problems and depleting stocks. The quarrying has left abandoned surfaces with excavated (walls, mine yards, pits) and accumulated forms (waste dumps) due to slow re-vegetation. Wine cellars, especially the multi-line World Heritage objects (e.g. Hercegkút, Fig. 8), are characteristic landscape shaping objects of the grape cultivation and winemaking traditions. The lithological conditions were appropriate to excavate in various length, predominantly into silicic pyroclastic rocks (Frisnyák 2012) and less frequently in Pleistocene loess (Tokaj Hill). The architecture, layout and length define the major cellar types (Müller 2013). The most popular is the simple-carved cellar, the larger ones deepen form above and closed with vault. The hall cellars previously operated as underground pyroclastite mines (rock dust). The layout (Fig. 6d) defines the simple one entry, parallel entry, main axis branched and larger hall-like arrangements (Frisnyák 2012). The most important cultural heritage object is the Ungvári wine cellar (Sátoraljaújhely, Fig. 8) where 27 individual cellars were joined horizontally and vertically to form 14-16 km long underground attraction. The cellar walls are often covered by noble rote and sometimes reveal a remarkable view of pyroclastic sedimentation structures (Fig. 6g) and a fragmentation pattern of perlitic lava domes.

The traditional TWR landscape demonstrates the long traditions of viticulture with dry-built terrace walls on the gentle volcanic slopes (Fig. 6h) defining a special land use pattern. 
Q15 t1.1 Table 1 Example of a geosite inventory sheet, Megyer Hill old millstone quarry (Fig. 6e, based on Fassoulas et al. 2012; Feuilliet and Sourp 2011)

\begin{tabular}{|c|c|c|c|c|c|c|}
\hline $\mathrm{t} 1.2$ & Geomorphosite & Geology & Mining and manufactory & $\begin{array}{l}\text { Other cultural } \\
\text { landscape features }\end{array}$ & Potential geosites & $\begin{array}{l}\text { Geoheritage } \\
\text { infrastructure }\end{array}$ \\
\hline $\mathrm{t} 1.3$ & \multicolumn{6}{|c|}{ Volcanic edifices: resulting from denudation and inversion of relief } \\
\hline $\mathrm{t} 1.4$ & \multicolumn{6}{|c|}{ Silicic lava dome/flow and pyroclastic deposit precinct } \\
\hline $\mathrm{t} 1.5$ & $\begin{array}{l}\text { Király-Megyer Hills } \\
\text { (Sárospatak) }\end{array}$ & $\begin{array}{l}\text { Eroded multi-phase submarine to } \\
\text { subaerial ash-flow succession with } \\
\text { strong hydrothermal alteration }\end{array}$ & $\begin{array}{l}\text { Millstone, clay minerals- } \\
\text { pottery, alunite, building } \\
\text { stone }\end{array}$ & $\begin{array}{l}\text { Old millstone quarry } \\
\text { with lake, vineyards }\end{array}$ & Quarries & Nature trail \\
\hline $\mathrm{t} 1.6$ & $\begin{array}{l}\text { Szokolya rhyolite lava } \\
\text { dome complex } \\
\text { (Erdőbénye) }\end{array}$ & $\begin{array}{l}\text { Intensive plinian and ash-flow } \\
\text { pyroclastic activity and } \\
\text { multi-phase lava dome extrusion } \\
\text { (11.0 Ma, obsidian, perlite, } \\
\text { rhyolite) }\end{array}$ & $\begin{array}{l}\text { Palaeolithic obsidian } \\
\text { resources, welded tuff } \\
\text { (Kispáca) }\end{array}$ & Vineyards & Rare outcrops, quarry & - \\
\hline $\mathrm{t} 1.7$ & $\begin{array}{l}\text { Sátor-Krakó Hills } \\
\text { (Abaújszántó) }\end{array}$ & $\begin{array}{l}\text { Erosion remnant of 11.3 Ma rhyolite } \\
\text { flow developed on older lava } \\
\text { dome and ash-flow tuff sequence }\end{array}$ & Rhyolite tuff (rock dust) & $\begin{array}{l}\text { Dry-built terrace walls } \\
\text { traditional wine } \\
\text { cellars }\end{array}$ & $\begin{array}{l}\text { Rhyolite tuff quarry, } \\
\text { panoramic viewpoints }\end{array}$ & Hiking routes \\
\hline $\mathrm{t} 1.8$ & Kakas Hill & $\begin{array}{l}\text { 12.8 Ma thick slightly silicified } \\
\text { ash-flow tuff sequence }\end{array}$ & $\begin{array}{l}\text { Most typical cultural } \\
\text { landscape building stones }\end{array}$ & $\begin{array}{l}\text { Vineyards, dry-built } \\
\text { terrace walls }\end{array}$ & Operating quarry & - \\
\hline $\mathrm{t} 1.9$ & Király Hill (Mád) & $\begin{array}{l}\text { 11.7 Ma hydrothermally altered } \\
\text { rhyolite lava dome, reddish } \\
\text { palaeosoil (nyirok) }\end{array}$ & $\begin{array}{l}\text { Kaolinite, montmorillonite, } \\
\text { quartzite }\end{array}$ & Dry-built terrace walls & Quarry & Nature trail \\
\hline $\mathrm{t} 1.10$ & $\begin{array}{l}\text { Szerencs Hills lava } \\
\text { domes }\end{array}$ & $\begin{array}{l}\text { Hydrothermally altered pyroclastites } \\
\text { and } 11.3 \text { Ma small rhyolite lava } \\
\text { domes eroded up to the vent } \\
\text { regions }\end{array}$ & $\begin{array}{l}\text { Tuffs and rhyolite building } \\
\text { stones, K rich }\end{array}$ & $\begin{array}{l}\text { Vineyards, dry-built } \\
\text { terrace walls }\end{array}$ & Rare outcrops, quarries & Hiking route \\
\hline $\mathrm{t} 1.11$ & \multicolumn{6}{|c|}{ Andesite and dacite cones and subvolcanic body precinct } \\
\hline $\mathrm{t} 1.12$ & Tokaj Hill & $\begin{array}{l}\text { 10.5 Ma composite volcano with } \\
\text { medium long dacite flows and } \\
\text { pyroclastites developed on eroded } \\
\text { ash flow and rhyolite dome } \\
\text { surface, Pleistocene loess cover }\end{array}$ & Dacite building stones & $\begin{array}{l}\text { Dry-built terrace walls } \\
\text { traditional wine } \\
\text { cellars }\end{array}$ & $\begin{array}{l}\text { Dacite quarries, loess } \\
\text { walls, Lebuj } \\
\text { rhyolite-perlite } \\
\text { outcrop }\end{array}$ & $\begin{array}{l}\text { Nature trail, } \\
\quad \text { hiking routes }\end{array}$ \\
\hline $\mathrm{t} 1.13$ & $\begin{array}{l}\text { Sátor Hills } \\
\text { (Sátoraljaújhely) }\end{array}$ & $\begin{array}{l}12 \text { Ma dacite composite volcano with } \\
\text { controversial origin (subvolcanic } \\
\text { /subaerial) developed on Badenian } \\
\text { ash-flow/fallout deposits }\end{array}$ & $\begin{array}{l}\text { Medieval } \mathrm{Au}-\mathrm{Ag} \text { mining, } \\
\text { building stone (dacite, } \\
\text { rhyolite, trass tuff) }\end{array}$ & $\begin{array}{l}\text { UNESCO Ungváry } \\
\text { cellar, traditional } \\
\text { cellars, dry-built } \\
\text { terrace walls }\end{array}$ & $\begin{array}{l}\text { Geyserite cone, quarries, } \\
\text { Au-Ag mining area, } \\
\text { panoramic viewpoints }\end{array}$ & $\begin{array}{l}\text { Nature trail } \\
\text { hiking routes }\end{array}$ \\
\hline $\mathrm{t} 1.14$ & Kopasz Hill (Tálya) & $\begin{array}{l}\text { 11.7 Ma columnar jointed olivine } \\
\text { bearing pyroxene andesite } \\
\text { subvolvanic intrusion, }\end{array}$ & Crushed stone & - & $\begin{array}{l}\text { Operating andesite } \\
\text { quarry }\end{array}$ & - \\
\hline $\mathrm{t} 1.15$ & Szegi Hill & $\begin{array}{l}\text { Erosion remnant of } 11 \text { Ma dacite } \\
\quad \text { flow on the silicic pyroclastites }\end{array}$ & - & $\begin{array}{l}\text { Vineyards, dry-built } \\
\text { terrace walls }\end{array}$ & - & Hiking route \\
\hline $\mathrm{t} 1.16$ & Mulató Hill & $\begin{array}{l}\text { Dacite (undated) laccolith with } \\
\text { intensive vesiculation and } \\
\text { mineralization (sulphide, } \\
\text { carbonate) intruded into sillcic } \\
\text { pyroclastite series (tuff, tuffite) and } \\
\text { remelted the hostrock }\end{array}$ & Crushed stone & $\begin{array}{l}\text { Vineyards, traditional } \\
\text { wine cellars }\end{array}$ & $\begin{array}{l}\text { Abandoned andesite } \\
\text { quarry }\end{array}$ & - \\
\hline $\mathrm{t} 1.17$ & \multicolumn{6}{|c|}{ Hydrothermal deposit precinct } \\
\hline $\mathrm{t} 1.18$ & $\begin{array}{l}\text { Botkő geyserite cone } \\
\text { (Sárospatak) }\end{array}$ & $\begin{array}{l}\text { Centre of the upwelling hydrothermal } \\
\text { fluids with intensive silicification } \\
\text { and cinnabar mineralization }\end{array}$ & Quartzite & - & Quarry & Nature trail \\
\hline $\mathrm{t} 1.19$ & $\begin{array}{l}\text { Erdőhorváti-Tolcsva } \\
\text { hydro-quartzite lodes }\end{array}$ & $\begin{array}{l}\text { Lodes of hydro-quartzite in variable } \\
\text { altered andesite, various } \\
\text { microcrystalline/amorphous quart } \\
\text { polymorphs (rhinestone, agate, } \\
\text { chalcedony) }\end{array}$ & Mineral collecting damage & - & $\begin{array}{l}\text { Small open pits and } \\
\text { debris }\end{array}$ & - \\
\hline $\mathrm{t} 1.20$ & $\begin{array}{l}\text { Ligetmajor diatomite } \\
\text { (Erdőbénye) }\end{array}$ & $\begin{array}{l}\text { Clayey bentonitic diatomite (2-3) } \\
\text { deposited on rhyolite tuff } \\
\text { epiclastites }\end{array}$ & $\begin{array}{l}\text { Diatomite, quartzite with } \\
\text { fossils }\end{array}$ & Wooded pasture & Quarry & - \\
\hline $\mathrm{t} 1.21$ & $\begin{array}{l}\text { Árpád Hill (Szerencs) } \\
\text { quartzite }\end{array}$ & $\begin{array}{l}\text { Blocks of the quartzite with remnants } \\
\text { of geysers cavity system }\end{array}$ & - & - & Outcrop & - \\
\hline $\mathrm{t} 1.22$ & $\begin{array}{l}\text { Megyaszó petrified } \\
\text { wood }\end{array}$ & $\begin{array}{l}\text { Silicified (opal) thermophilic flora } \\
\text { (Ulmus, Betula, Carpinus) trees } \\
\text { and branches in Pannonian } \\
\text { sediments }\end{array}$ & - & - & Quarry and debris & - \\
\hline
\end{tabular}

694 The walls installed to protect soil against erosion and facilitate

695 slope cultivation were first mentioned in archival documents

696 from the seventeenth century (Balassa 1991). The terrace walls were constructed by constant removing of larger boulders coming to the surface by cultivation or on the occasion of one fold landscaping of the terrain (Incze and Novák 2013; 
Novák and Incze 2014). In both cases, the stones used for construction reflect the local lithological diversity, the shape and pattern of walls displaying the relief characteristics and the local knowledge on how to maintain soil fertility during several hundreds of years (Novák et al. 2014). Terraced slopes and walls appear on about 590 ha $(11.3 \%)$ within the wine region, most frequently at steeper $(>17 \%)$ slopes (Incze and Novák 2016). Except for a few reconstructed and cultivated terraces, most of them are abandoned and subjected to secondary succession (Nyizsalovszki and Fórián 2007). In lack of further management, their collapse is predictable causing significant loss of this characteristic landscape features, which are representing cultural and natural values at the same time. Recognizing those as important geodiversity sites could help in the effective geoconservation.

\section{Inventory and Preliminary Geosite Assessment of the Tokaj Wine Region}

The inventory of geosites is the first and crucial step in analysis of geodiversity (Brilha 2015). The first important step in this stage is the evaluation of geological and geodiversity sites with the aim to use them particularly for touristic and educational purposes. In Hungary, systematic description and characterization of the geological heritage are lacking in the national geoconservation strategy. Thus, this initial inventorying and assessment could promote such work in other areas of the country. The inventorying area is primarily the TWR but later is has to be extended to the north to involve the continuation of the volcanic area of the Tokaj Mts. Our methodology follows the traditional framework (e.g. Coratza et al. 2011) with bibliographical revision and building GIS database with topographic (1:10,000), geological maps (1: 25,000), and digital DEM (SRTM) and landcover (CORINE Land Cover 2006 seamless vector data 2016) databases. During the detailed fieldwork, general and descriptive data were recorded with volcanological-geological information and the human impacts on the landscape. We selected and evaluated those landscape features, which had significant contribution in the perception and understanding of regional geomorphological evolution according to their scientific, educational and aesthetic value, current condition and accessibility. The accurate definition of the site characteristics is particularly important in choosing objects for subsequent multi-faceted priority analysis.

The Megyer Hill ancient millstone quarry was selected as an important geosite example because of their local and regional significance in geology-volcanology, geoconservation and tourism (Szepesi and Ésik 2015). The geosite inventory sheet contains the major inventoried attributes (Table 2). The preliminary inventory (Ésik et al. 2015) recognized 40 TWR geosites. The volcano-geomorphological forms and processes were identified, listed and mapped (Table 1, Fig. 3b) We note that in some cases, the geologically important value and its rarity in the site can be recognized, but more research would be necessary to support it by scientific data. Thus, the scientific value can be clearly defined (rarity, number of written papers, interpretation level; Vujicic et al. 2011), but more study would be necessary to highlight their importance in geoeducational programme and tourism.

The inventory has to be followed by several successive stages (assessment, interpretation, promotion, monitoring) to establish a regional geoconservation strategy. There is no standardized method to quantify the importance of a geosite or geodiversity sites and evaluate their scientific and/or their educational/touristic values (Bruschi and Cendrero 2009; Pereira and Pereira 2010; Vujicic et al. 2011; Reynard et al. 2015). Brilha (2015) provided criteria, indicators and parameters, what can be used in the quantitative assessment; however, in this study, we used the geosite assessment model (GAM) proposed by Vujicic et al. (2009). This was applied also by Moufti and Németh (2013) for the volcanic area of Saudi Arabia. The GAM involves main values from additional values that can be measured by objective values. The main values comprise three groups of variables: (1) scientific/ educational value (VSE), (2) scenic/aesthetic value (VSA) and (3) protection (VPr). The VSE can be further divided into rarity, representativeness, knowledge on geoscientific issues and level of interpretation. The VSA contains variables such as viewpoints, surface, surrounding landscape and nature, and environmental fitting of sites. The VPr consists of current condition, protection level, vulnerability and suitable number of visitors. The additional values are gathered into (1) functional values (VFn) and (2) touristic values (Vtr). The major indicators of VFn are accessibility, additional natural values, additional anthropogenic values, vicinity of emissive centres (e.g. main cities) and vicinity to main roads (or rail network). The VTR is calculated by estimating the promotion, annual number of organized visits, vicinity to a visitor centre, existence of interpretative panels, annual number of visitors, tourism infrastructure, tour guide services, hostelry services and restaurant services. Each indicator is ranked between 0 and 1 values. In the total sum, there are 12 subindicators of main values and 15 subindicators of additional values that define GAM in an unweighted, simple equation:

$$
\begin{aligned}
\mathrm{GAM}= & \text { main values }(\mathrm{VSE}+\mathrm{VSA}+\mathrm{VPr}) \\
& + \text { additional values }(\mathrm{VFn}+\mathrm{VTr})
\end{aligned}
$$

Based on the result of the evaluation process, the main values ( $X$ axis) and the additional values ( $Y$ axis) define a nine-field matrix (Fig. 7). The position of the evaluated site indicates the current conditions of scientific recognition, conservation and tourism development. Vujicic et al. (2011) 


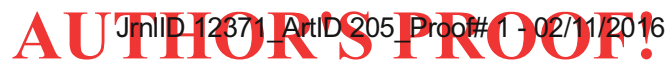

Geoheritage
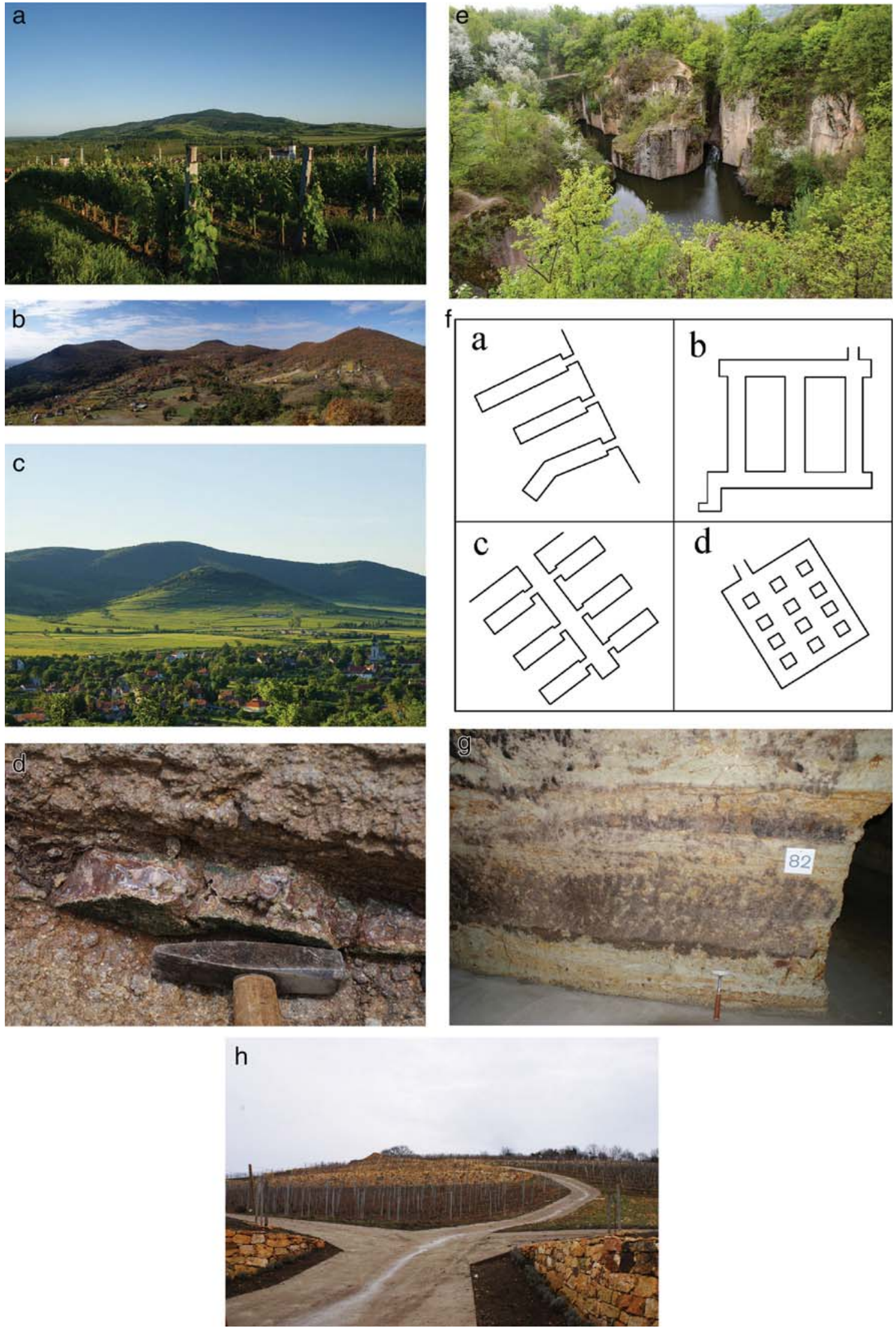
4 Fig. 6 Classification of the geoheritage objects of Tokaj Wine Region Historic Cultural Landscape: Volcanic edifices, resulting from denudation and inversion of relief. a The eponymous Tokaj Hill dacite composite cone, symbol of the Tokaj wine region. b Semicircular peaks of Sátor Hill group composite dacite cone, inspiring imagine an ancient volcanic crater, as high priority object, regional centre of cross border active and geotourism activities. c A small-scale form: Vár Hill (Bodrogszegi) a dacite capped erosional butte. d Chalcedony vein in altered andesite (Erdöhorváti) with strong interest of mineral collecting activities Geodiversity sites connected to land use traditions of the Cultural Landscape. e Megyer Hill, old millstone quarry, with a picturesque lake attract tourist and classified as high priority geosites. $\mathbf{f}$ Layout types of wine cellars (Frisnyák 2002): $a$ the simple, one entry, $b$ parallel entry, $c$ main axis branched, $d$ larger hall like arrangements. g Pyroclastite layering in Moonwalley Wines cellar (Mád). h Newly renovated drybuilt terrace walls (Mád). Photos by János Szepesi and Moufti and Németh (2013) emphasized that the geositesgeodiversity sites with high and additional values could be the principal places of (geo)tourism, while in the case of the lower scored object, significant development (infrastructure, interpretation level) is necessary. This is clearly illustrated by the high values of the well-known localities in the Bakony-Balaton Geopark (Tihany and Hegyestü), in the Novohrad-Nógrád Geopark (Ipolytarnóc) and in the the Ság hill, where the Kemenes Volcano Park was designed (Fig. 7). Concerning the TWR, the geotopes/ geosites belonging to the large composite cones have high main and additional GAM values. Their cultural and/or religious (calvary) significance is also important for the local community. The spectacular Tokaj Hill is an eponymous cone of the wine region (Fig. 6a) and a place of the Hungarian Geotope Day education event. The Sátor Hills (Sátoraljaújhely, Fig. 6b) is the centre of active cross border tourism (Zemplén Adventure Park). The further geosites are scattered with higher main and medium to low additional values that reflect their scientific values and their potential for further development. This could involve educational trails, interpretative elements, visitor centres, etc. Some of the geosites are severely impaired by illegal mineral collecting activities, which require effective conservation restrictions. The quarries are represented by various GAM coordinates (medium to low) and the still operating mines usually have smaller additional values. The old millstone quarry of Megyer Hill (Fig. 6e) is ranked by the highest main value, although the renewed nature trail requires further improvement with geotouristic infrastructure (e.g. interpretation panels). The well-known UNESCO wine cellars (Rákóczi Cellar, Sátoraljaújhely, Ungvári Wine Cellar, Sárospatak) have high GAM values, whereas the smaller cellars are without any scientific interests. The dry-built terrace walls are common land use elements in the vineyards and have the lowest main values. On the contrary, the vicinity to the touristic infrastructure resulted in usually elevated additional values. Nevertheless, at this stage, they belong to the low priority sites in a touristic point of view.

\section{Discussion and Conclusions}

The Carpathian-Pannonian region in eastern-central Europe provides a unique insight into the nature of volcanic formations formed by a wide range of volcanic activities over the last 20 Ma. The spectacular volcanic heritage (Harangi 2014; Ésik et al. 2015; Szepesi and Ésik 2015) offers a new way for geotourism, which could initiate the recovery of economy in otherwise disadvantaged regions. Although there are two geoparks and a volcano park in Hungary, a systematic inventory and assessment of geosites are still lacking. This would be an essential step to establish a geoconservation strategy, to mark the priorities (e.g. geotourism) in site management (Brilha 2016; Reynard et al. 2015) and also to provide scientific basis for the proposed Pannonian Volcano Route (Harangi et al. 2015).

The TWR is a World Heritage Site based on the long tradition of viticulture. It focuses on the viticulture traditions and wine tourism only; however, we demonstrated here that it contains valuable geoheritage what could be an integrated part of the touristic market. This area belongs to the Tokaj-Slanske vrchy volcanic chain, a unique andesitic-rhyolitic volcanic field formed during the middle Miocene and is planned to be the starting point for the cross-country thematic Pannonian Volcano Route. Three main precincts can be defined here: (1) silicic lava dome/flow and pyroclastic deposit precinct, (2) andesite and dacite cones and subvolcanic body precinct and (3) hydrothermal deposit precincts. Each of them is composed of further geotopes and geosites as well as ex situ geoheritage elements based on their scientific values, whereas there are additional geodiversity elements (e.g. cellars, quarries, dry-built terrace walls) what link the geological features with the local tradition of viticulture. The raw material exploration has thousand years of history in the region from Palaeolithic obsidian. The rhyolite tuffs providing building stones, the pottery supported by clay minerals and the perlites used in glassworks. The silicified pyroclastites were used to carve quality millstones as early as the fifteenth century. The viticulture roots through the accumulation of a special clayey cobbly loam and reaches the bedrocks which are therefore responsible for the local characteristics of grapes and wines. The cellars and dry-built terrace walls are integrated elements both the geodiversity and the viticulture. Furthermore, the volcanic area of the TWR played a significant role also in the early geological history in the eighteenth and nineteenth centuries, what elements can be effectively built up into the geoheritage value. In summary, geoheritage of the TWR offers a complex view of the andesitic to rhyolitic volcanism from the
842 843 844 845 846 847 848 849 850 851 852 853 854 855 856 857 858 859 860 861 862 863 864 865 866 867 868 869 870 871 872 873 874 875 876 877 878 879 880 881 882 883 884 885 886Q20 887 888 
t2.1 Table 2 Characteristics of Tokaj Wine Region Cultural Landscape geomorphosites, summary of geology, cultural landscape features and the current state of geotourism activities

t2.2 Geomorphosite evaluation sheet

t2.3 Identification

t2.4 Situation

t2.5 Site

t2.6 Geosite attributes

t2.7 Main interest

t2.8 Secondary interest

t2.9 Geology, volcanology, geomorphology Rock

t2.14 Geodiversity

t2.15 Biodiversity

t2.16 Viewpoints

t2.17 Landscape difference

t2.18 Protection status

t2.19 Scientific awareness

t2.20 Mining and Manufactory

t2.21 Accessibility

t2.22 Public awareness

t2.23 Visitors number

t2.24 Touristic values

t2.25 Intensity of use

t2.26 Fragility

t2.27 Natural risks

$\begin{array}{lll}\text { Name: old millstone quarry } & \text { Area: Király-Megyer Hill } & \text { Code: KMA3 } \\ \text { Coordinates: } 48^{\circ} 21^{\prime} 26^{\prime \prime} \mathrm{N}, 21^{\circ} 34^{\prime} 21^{\prime \prime} \mathrm{E} & \text { Elevation: } 285 \mathrm{~m} \\ \text { Type 1: geological basic profile } & \text { Type 2: quarry }\end{array}$

Submarine, lapilli tuff, hydrothermal alterations, quarry, millstone manufacturing, natural reserve

Picturesque lake in the quarry yard with the vertical quarry walls

Geodiversity, biodiversity

Pumice breccia with high abundance of angular/rounded lithic clasts (perlitic lapille)

Interpretation Pyroclast flow and fall sequence deposited in dominantly submarine environment

Alterations Various hydrothermal alterations: silicification, alunite, kaolinite

Chronology Mollusca fauna (Chlamys, Cardium, Isocardia) - mid-Miocene/Badenian stage

Morphology Semicircular erosional range with a local basin opening to south (selective erosion)

Various pyroclastic rocks (lapilli tuffs) and hydrothermal alterations (silicification, argillations) (geyserite) and mineralization (alunite, cinnabar, kaolinite)

Maple-oak woods (Averi tatarico-Quercetum) waterside and aquatic plants duckweeds (Lemna minor, Lemna)

Number of viewpoints accessible by a pedestrian pathway

High, quarry lake, maple-oak woods, vineyards

Nature conservation area of national interest (1997) UNESCO World Heritage buffer zone

High, World Geomorphological Landscapes series, Springer 2015

Millstone: from fifteenth century, kaolinite: 1887-1940, alunite 1977-1985, quartzite:

1950-1990, millstone, pottery, tile stove and pipe factories

Medium, dirt road and pedestrian pathway (nature trail) access

High, Hungary's most beautiful natural attraction (internet voting 2011)

Higher, $5000<$

Vicinity of larger city, interpretative panels, garbage cans

Higher, on weekends $100<$

Low

Low, scrubby-woody vegetation around the walls need control for better visibility primary volcanic features to the subsequent alteration and mineralization and from the significant role in the historical geological recognition to the close link with the traditional viticulture.

The preliminary study in the TWR, presented in this paper, is the first detailed evaluation of the geosite and geodiversity sites in Hungary. Albert and Csillag (2011) compiled a set of localities with geological interests in the Balaton Upland area; however, they gave only a brief description of the sites without a systematic assessment and evaluation. Application of the proposed methodology (Brilha 2016; Reynard et al. 2015) followed here yields, however, a benefit to place the recognized geoheritage in an international geotouristic and geoconservation context. Nevertheless, this is still the very start of the work and more effort is necessary to obtain a coherent picture about the geotouristic value of the area. The quantitative assessment of the selected localities, which candidate to become geosites, revealed that the geological values often require additional scientific work to justify the representativeness and rarity and the suitability to introduce them into geoeducation programme and geotourism. The volcanic area can be classified as 'Volcanic landform resulting from denudation and inversion of relief' (Wood 2009), and as a results of strong erosion, the root zone of the volcanoes has been revealed offering a special insight into their deeper structure of the volcanic edifices including shallow intrusive bodies and ore mineralization. The extended silicic volcanism involving both effusive (various lava domes and rhyolitic lava flows) and explosive products (ignimbrite sheets) is unique in the Carpathian-Pannonian region and possibly resembles the modern activity of the Laguna del Maule area, at the ChileArgentina border zone (Singer et al. 2014). Furthermore, this volcanic area in overall can be comparable with the present Kagoshima graben and Taupo zone volcanism. These analogues can be used for geoeducational purposes to attract people and to teach how volcanoes work. 
Geoheritage

Fig. 7 Preliminary geosite assessment of the Tokaj Wine Region Historic Cultural

Landscape volcanic geoheritage, with priority fields of the tourism interest and further development possibilities including the most important geosites of Pannonian Volcano Route for comparison

Fig. 8 Geosite assessment map of the Tokaj wine region. The radius of the circles is proportion of additional value of the sites, referring their geotourism priority ranking
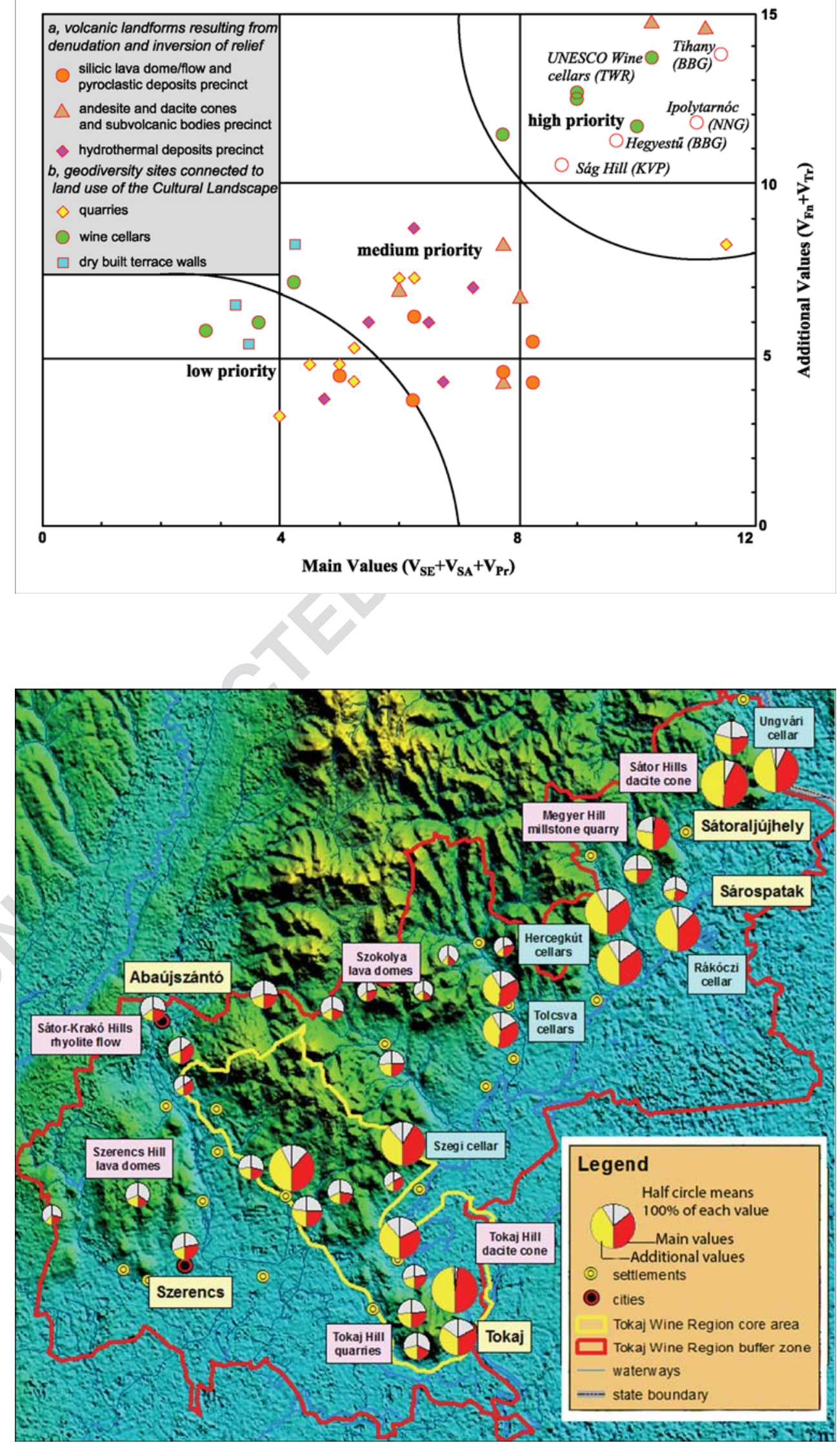
The first assessment of the inventoried 40 potential geosites combined the evaluation of scientific, cultural/historical, aesthetic and socio-economic values. The preliminary result (Figs. 7 and 8) enables to classify them into three main groups: low, medium and high priority objects (Feuilliet and Sourp 2011). The low priority objects (low GAM coordinates) involve the operating mines, terrace walls and simple wine cellars with minor geotourism interest. The medium priority sites (medium main values, moderate management scores) are the small volcanic bodies, hydrothermal deposits and abandoned quarries with the possibility of enhancing geotourism interest. Finally, the high priority sites (highest GAM coordinates) comprise the unique composite volcanic cones (e.g. Tokaj Hill, Sátor Hills) and the World Heritage cellars, which must be considered for further (geo)touristic development. However, in an UNESCO World Heritage cultural site, it needs particular efforts to demonstrate that geological values could have a significant additional element of the destination brand and could enhance tourism. Therefore, it is important to deliver the result of the inventory and assessment of the potential geoheritage to touristic value and introduce new elements to attract people. The proposed Pannonian Volcano Route with the first stops in the TWR followed by an initiation to establish a geopark could help in this programme; however, further works are crucial to set the geoheritage more visible not only in the TWR but also in Hungary.

\section{References}

Albert G, Csillag G (2011): Geo-helyszínek a Káli-medencében. http://www.elgi.hu/hu/node/417. Accessed 26 Feb 2016

Aramaki S (1984) Formation of the Aira Caldera, southern Kyushu, 22, 000 years ago. J Geophys Res 89:8485-8501

ArcGIS Online (2016) UNESCO World Heritage Sites. http://www. arcgis.com/home/webmap/viewer.html. Accessed 20 Feb 2016

Bajnóczi B, Molnár F, Maeda K, Izawa E (2000) Shallow level lowsulphidation type epithermal systems in the Regec caldera, Central Tokaj Mountains, NE-Hungary. Geol Carpath 51:217-227

Bakony-Balaton Geopark (2016). http://www.geopark.hu. Accessed 26 Feb 2016

Balassa I (1991) Tokaj-Hegyalja szőlője és bora Tokaj-Hegyaljai ÁG. Borkombinát, Tokaj, p. 752

Banska Stiavnica Mesto svetového. Dec

Brilha J (2002) Geoconservation and protected areas. Environ Conserv 29(3):273-276

Brilha $\mathbf{J}$ (2015) Inventory and quantitative assessment of geosites and geodiversity sites: a review. Geoheritage 8:116. doi:10.1007 /s12371-014-0139-3

Brocx M, Semeniuk V (2007) Geoheritage and geoconservation-history, definition, scope and scale. J R Soc West Aust 90:53-87

Bruno DE, Crowley BE, Gutak JM, Moroni A, Nazarenko OV, Oheim KB, Ruban DA, Tiess G, Zorina SO (2014) Paleogeography as geological heritage: developing geosite classification. Earth Sci Rev 138:300-312

Bruschi VM, Cendrero A (2009) Direct and parametric methods for the assessment of geosites and geomorphosites. In: Reynard E, Coratza
P, Regolini-Bissig G (eds) Geomorphosites. Pfeil, Munchen, pp. 7388

Bujdosó Z, Pénzes J (2012) The spatial aspects and distribution of the touristic development resources in the border microregions of Hungary. In: Roma population on the peripheries of the Visegrad countries: spatial trends and social challenges/Pénzes János, Radics Zsolt, Didakt Kft., Debrecen, pp 226-239

Bujdosó Z, Baros Z, Dávid L, Baiburiev R, Gyurkó Á (2015) Potential use of the coal and ore mining related industrial heritage for tourism purposes in the North Hungarian region. Acta Geoturistica 6(1):2129

Cas RAF, Wright JV (1987) Volcanic successions, modern and ancient. Allen and Unwin, London, p. 528

Cayla N (2014) Volcanic geotourism in France. In: Erfurt-Cooper P (ed) Volcanic tourist destinations. Springer, pp 131-138

Cole JW (1990) Structural control and origin of volcanism in the Taupo volcanic zone, New Zealand. Bull Volcanol 52:445-459

Coratza P, Bruschi VM, Piacentini D, Saliba D, Soldati M (2011) Recognition and assessment of geomorphosites in Malta the IlMajjistral Nature and History Park. Geoheritage 3:175-185

CORINE Land Cover 2006 seamless vector data (2016). http://www.eea. europa.eu/data-and-maps/data/clc-2006-vector-data-version. Accessed 26 Feb 2016

Dávid, L. (2008) Quarrying and other minerals. In: Szabó J, Dávid L, Lóczy D (eds) Anthropogenic geomorphology: a guide to manmade landforms. Springer, pp 185-200

Edelsbacher F, Koch W (2001) Vulkanland - dorfgrenzen-grenzenlos. Graz Wien Koln, Styria

Edinburgh World Heritage City (2011) The old and new towns of Edinburgh Word Heritage Site Management Plan 2011-2016, pp $1-96$

Erfurt-Cooper P (2011) Geotourism in volcanic and geothermal environments: playing with fire? Geoheritage 3(3):187-193

Erfurt-Cooper P (ed) (2014) Volcanic tourist destinations. Springer, p 384

Erfurt-Cooper A, Cooper M (2010) Volcano and geothermal tourism: sustainable geo-resources for leisure and recreation. Earthscan, London, p. 378

Ésik Z, Szepesi J, Rózsa P (2015) Geosite inventory and assessment of Tokaj Wine Region, Historic Cultural Landscape, Hungary. 2nd Volcandpark Conference, Lanzarote Abstract Book, pp 6-7

Esmark J (1798) Kurze Beschreibung einer mineralogischen Reise durch Ungarn. Siebenbürgen und das Bannat, Freyberg

Fassoulas C, Mouriki D, Dimitrou-Nikolakis P, Iliopoulos G (2012) Quantitative assessment of geotopes as an effective tool for geoheritage management. Geoheritage 4:177-193

Feuilliet T, Sourp E (2011) Geomorphological heritage of the Pyrenees National Park (France): assessment, clustering and promotion of geomorphosites. Geoheritage 3:151-162

Fichtel JE (1791) Mineralogische Bemerkungen von den Karpathen. I-II. - Vienna

Fichtel, JE (1794) Mineralogische Aufsätze. - Vienna

Frey ML, Schäfer K, Büchel G, Pat M (2006) Geoparks-a regional, European and global policy. In: Dowling RK, Newsome D (eds) Geotourism, pp 95-118

Frisnyák S (2012) A Tokaj-Hegyaljai borpincék földrajzi vázlata. In: Frisnyák S, Gál A (eds) Tokaj-hegyaljai borvidék hazánk első történeti tája, pp 157-171

Fuertes-Gutierrez I, Fernandez-Martinez E (2010) Geosites inventory in the Leon Province (northwestern Spain): a tool to introduce geoheritage into regional environmental management. Geoheritage 2:57-75

Fuertes-Gutierrez I, Fernandez-Martinez E (2012) Mapping geosites for geoheritage management: a methodological proposal for the regional park of Picos de Europa (Leon, Spain). Environ Manag 50(5): 789-806 
Geoheritage

Gadányi P (2015) Buttes in the Tapolca basin. In: Lóczy D (ed) Landscapes and landforms of Hungary. Springer, pp 63-70

German Volcano Route (2016). http://www.deutsche-vulkanstrasse.com. Accessed 26 Feb 2016

Global Geopark Network (2012) Statutes of the international geoscience and geopark programme. http://www.globalgeopark. org/UploadFiles/2012 9 6/IGGP_EN_Statutes and Guidelines. pdf. Accessed 21 Aug 2016

Gonggrijp GP (1997) Geotope motivation and selection: a way of objectifying the subjective. In: Marinos PG, Koukis GC, Tsiambaos GC, Stournaras GC (eds) Engineering geology and the environment, vols 1-3, pp 2949-2954

Gray JM (2008) Geodiversity: developing the paradigma. Proc Geol Assoc 119:287-298

Gross M, Fritz I, Piller WE, Soliman A, Harzhauser M, Hubmann B, Moser B, Scholger R, Suttner TJ, Bojar HP (2007) The Neogene of the Styrian basin — guide to excursion. Joannea Geol Paläont 9: 117-193

Gyarmati P, Szepesi J (2007): Fejlődéstörténet, földtani felépítés, földtani értékek in: Baráz Cs, Kiss G (eds) A Zempléni Tájvédelmi Körzet, Abaúj és Zemplén határán Bükki Nemzeti Park, Eger pp 15-44

Hably L (1985) Ipolytarnóc alsó-miocén korú flórája (early Miocene plant fossils from Ipolytarnóc, N Hungary). Geol. Hung., Ser. Palaeontol. 45:73-255

Harangi S (2001) Neogene to quaternary volcanism of the CarpathianPannonian region - a review. Acta Geol Hung 44:223-258

Harangi S (2014) Volcanic heritage of the Carpathian-Pannonian region in eastern-central Europe. In: Erfurt-Cooper P (ed) Volcanic Tourist Destinations. Springer, pp 103-124

Harangi S (2015) Vulkánok. A Kárpát-Pannon térség tűzhányói. Geolitera, Szeged 2nd edition, p 482

Harangi R, Harangi S (1995) Volcanological study of the Neogene basaltic volcano of Sághegy (little Hungarian plain volcanic field, western Hungary). Acta Vulcanol 7(2):189-197

Harangi S, Lenkey L (2007) Genesis of the Neogene to quaternary volcanism in the Carpathian-Pannonian region: role of subduction, extension, and mantle plume. Geol Soc Am Spec Pap 418:67-92

Harangi S, Németh K, Korbély B, Szepesi J, Szarvas I, Lukács R (2015) The Pannonian Volcano Route-volcanological heritage and geotouristic perspectives. 26th IUGG General Assembly, Abstract: IUGG-4802

Henriques MH, dos Reis RP, Brilha J, Mota T (2011) Geoconservation as an emerging geoscience. Geoheritage: $1-12$

Herčko P, Domaracká L, Ambroš P (2014) Mining Bethlehem at Banská Štiavnica-example of mining heritage in Slovakia. Acta Geoturistica 5(2):64-68

Hoenig HG (2005) Geothermal resources as a promoter of regional development, The success story of the Styrian volcanic region Proceedings World Geothermal Congress 2005 Antalya, Turkey, pp 1-8

Horváth G, Lóczy D (2015) Geoheritage, geoconservation, geomorphosites in Hungary. In: Lóczy D (ed) Landscapes and landforms of Hungary. Springer, pp 281-288

Horváth F, Bada G, Szafián P, Tari G, Ádám A, Cloetingh S (2006) Formation and deformation of the Pannonian Basin: constraints from observational data. Geological Society, London, Memoirs 32(1):191-206

Hovorka D, Illasova L (2010) The Tokaj Mts. obsidian - its use in prehistory and present application. In: Proceedings of the XIX CBGA Congress, Thessaloniki, Greece Special Volume 100:385-390

Hroncek P (2015) Local quarries and how to use them in geotourism. Acta Geoturistica 6(1):11-20

Incze J. and Novák, T. J. (2013) Geomorphological characteristic and significance of dry constructed terrace stone walls on abandoned vine-plantations in Tokaj Big-Hill. In: Novotny J, Lehotsky M, Raczkowska Z, Machova Z (eds) 2013. Carpatho-Balkan-Dinaric conference on geomorphology book of abstracts, Geomorphologia Slovaca et Bohemica, 13, p 33

Incze J, Novák T J (2016) Identification of extent, topographic position and land abandonment processes of vineyard terraces in TokajHegyalja wine region between 1784 and 2010. J Maps (in Press)

Ipolytarnóc Paleontological Site (2016). http://osmaradvanyok.hu/index. php?p=hu_home. Accessed 26 Feb 2016

Joyce B (2009) Geomorphosites and volcanism. In: Reynard E, Coratz P, Regolini-Bissing G (eds) Geomorphosites. Pfeil, München, pp. $175-188$

Kagermeier A (2010) Experience orientated staging of nature oriented and geotourism attractions - a case study from the European Geopark Vulkaneifel. In: Kagermeier A, Willms J (eds) Tourism development in low mountain ranges. Mannheim, pp 23-46

Karátson D (2007) A Börzsönyől a Hargitáig—Vulkanológia, felszínfejlődés, ősföldrajz. Typotex Kiadó, Budapest, p. 463

Kemenes Volcano Park (2016). http://www.kemenesvulkanpark.hu/. Accessed 26 Feb 2016

Komlos J 1983 The Habsburg Monarchy as a customs union: economic development in Austria-Hungary in the nineteenth century, p. 370

Konecny, V., Kovac, M., Lexa, J., Sefara J. 2002 Neogene evolution of the Carpatho-Pannonian region: an interplay of subduction and back-arc diapiric uprise in the mantle. - European Geosciences Union, Stephan Mueller Special Publication Series, 1, 105-123,

Kordos L (1985) Lábnyomok az ipolytarnóci alsó-miocén korú homokkőben (footprints in lower Miocene sandstone at Ipolytarnóc, N Hungary). Geol Hung, Ser Palaeontol 46:257-415

Kršák B, Štrba L, Lukáč M, Sidor C, Molokáč (2015) Impact of geopark establishment on regional tourism development; case study from Slovak part of the Novohrad-Nógrád Geopark. Acta Geoturistica, volume 6(2):30-38

Kubalikova L (2013) Geomorphosite assessment for geotourism purposes. Czech Journal of Tourism 2:80-104

Lexa J, Seghedi I, Németh K, Szakács A, Konecny V, Pécskay Z et al (2010) Neogene-quaternary volcanic forms in the CarpathianPannonian region: a review. Central European Journal of Geosciences 2:207-270

Lima FF, Brilha JB, Salamuni E (2010) Inventorying geological heritage in large territories: a methodological proposal applied to Brazil. Geoheritage 2(3-4):91-99. doi:10.1007/s12371-010-0014-9

Macdonald GA (1972) Volcanoes. Prentice-Hall, NJ, p. 510

Martin U, Németh K (2004a) Mio/Pliocene phreatomagmatic volcanism in the western Pannonian Basin. Geologica Hungarica, Series Geologica tomus 26, Budapest, pp 191. ISBN:963-671- 238-7

Martin U, Németh K (2004b) Peperitic lava lake-fed sills at Ság-hegy, western Hungary: a complex interaction of a wet tephra ring and lava. In: Breitkreuz C, Petford N (eds) Physical geology of highlevel magmatic systems, vol 234. Geological Society, Special Publications, London, pp. 33-50

Mátyás E (2005) A Tokaji-hegységi nemfémes ásványi nyersanyagok földtani kutatásának és bányászatának története. In: Mátyás EA (ed) Tokaji-hegység geologiája és ásványi nyersanyagai egy geológus életútja tükrében, pp 297-362

Mester Zs. Rácz B (2010) The spread of the Körös culture and the raw material sources in the northeastern part of the Carpathian Basin: a research project. In: Kozłowski JK, Raczky P (ed) 2010 Neolithization of the Carpathian Basin: northernmost distribution of the Starčevo/Körös culture Kraków-Budapest, pp 23-57

Molnár F (1993) Tokaji-hegységi ércesedések és indikációk genetikája folyadékzárvány vizsgálatok alapján PhD értekezés Eötvös Loránd Egyetem

Molnár F, Zelenka T, Mátyás E, Pécskay Z, Bajnóczi B, Kiss J, Horváth I (1999) Epithermal mineralization of the Tokaj Mountains, Northeast Hungary; shallow levels of low-sulfidation type systems. Guidebook Series-Society of Economic Geologists 31:109-153 
Moufti MR, Németh K (2013) The intra-continental Al Madinah volcanic field, western Saudi Arabia: a proposal to establish Harrat Al Madinah as the first volcanic geopark in the Kingdom of Saudi Arabia. Geoheritage 5(3):185-206

Moufti MR, Németh K, Murcia H, Al-Gorry SF, Shawali J (2013a) Scientific basis of the geoheritage and geotouristic values of the 641 AD Al Madinah eruption site in the Al Madinah volcanic field, Kingdom of Saudi Arabia. The Open Geology Journal 7:31-44

Moufti MR, Németh K, Murcia H, Lindsay J (2013b) The 1256 AD Al Madinah historic eruption geosite as the youngest volcanic chain in the Kingdom of Saudi Arabia. Int J Earth Sci 102(4):1069-1070

Moufti MR, Németh K, El-Masry N, Qaddah A (2014) Volcanic geotopes and their geosites preserved in an arid climate related to landscape and climate changes since the Neogene in northern Saudi Arabia: Harrat Hutaymah (Hai'il region). Geoheritage 7(2):103-118

Müller I (2013) A Tokaj-hegyaljai pincék múltja, értékei és sorsa, pp 1-22 Neches I-M (2016) Geodiversity beyond material evidence: a geosite type based interpretation of geological heritage. Proceedings of the Geologists' Association (in press)

Newsome D, Dowling RK (eds) (2010) Geotourism: the tourism of geology and landscape. Goodfellow Publishers Ltd., Oxford

Novák TJ, Incze J (2014) Retaining walls of abandoned vineyard terraces on Tokaj Nagy Hill, 4D. Journal of Landscape Architecture And Garden Art 35:20-35

Novák TJ, Incze J, Spohn M, Glina B, Giani L (2014) Soil and vegetation transformation in abandoned vineyards of the Tokaj Nagy-Hill. Catena 123:88-89

Novohrad-Nógrád Geopark (2016). http://www.nogradgeopark.eu/. Accessed 26 Feb 2016

Nyizsalovszki R, Fórián T (2007) Human impact on the landscape in the Tokaj foothill region. Hungary Geogr Fis Din Quat 30:219-224

Ólafsdóttir R, Dowling R (2014) Geotourism and geoparks - a tool for geoconservation and rural development in vulnerable environments: a case study from Iceland. Geoheritage 6(1):71-87

Pálfy J, Mundil R, Renneb P, Bernor R, Kordos L, Gasparik M (2007) U$\mathrm{Pb}$ and $40 \mathrm{Ar} / 39 \mathrm{Ar}$ dating of the Miocene fossil track site at Ipolytarnóc (Hungary) and its implications. Earth Planet Sci Lett 258:160-174

Panizza M (2001) Geomorphosites: concepts, methods and example of geomorphological survey. Chin Sci Bull 46(Suppl. Bd):4-6

Pécskay Z, Molnár F (2002) Relationships between volcanism and hidrothermal activity in the Tokaj Mountains, Northeast Hungary. Geol Carpath 53:303-314

Pécskay Z, Balogh K, Székyné FV, Gyarmati P (1987) A Tokaji-hegység miocén vulkánosságának K/Ar geokronológiája Földt. Közl 11: 237-253

Pécskay Z, Balogh K, Széky-Fux V, Gyarmati P (1989) Geochronological investigations on the Neogene volcanism of the Tokaj Mountains. Can J Soil Sci 69:635-655

Pécskay Z, Lexa J, Szakács A, Balogh K, Seghedi I, Konecný V, Kovác M, Márton E, Széky-Fux V, Póka T, Gyarmati P, Edelstein O, Rosu E, Zec B (1995) Space and time distribution of Neogene-quaternary volcanism in the Carpatho-Pannonian region. Acta Volcanologica 72:5-29

Pénzes J (2013) The dimensions of peripheral areas and their restructuring in Central Europe. Hungarian Geographical Bulletin 62(4):373-386

Pereira P, Pereira DI (2010) Methodological guidelines for geomorphosite assessment. Géomorphol Relief, Processus, Environ 2:215-222

Reynard E, Fontana G, Kozlik L, Scapozza C (2007) A method for assessing "scientific" and "additional values" of geomorphosites. Geographica Helvetica Jg. 62. Heft 3:148-158

Reynard E, Perret A, Bussard J, Grangier L, Martin S (2015) Integrated approach for inventory and management of geomorphological heritage at the regional scale. Geoheritage:1-20. doi:10.1007/s12371015-0153-0
Richthofen F (1860) Studien aus dem Ungarisch-Siebenbürgischen Trachytgebirgen. Jahrb K K geol Reichsanstalt 11:153-278

Rózsa P (1994) The dacite flows of the Miocene Tokaj-Nagyhegy stratovolcano: an example of magma mixing. Geologica Carpathica Bratislava 45:139-144

Rózsa P (2003) Activities of volcanist and neptunist 'natural philosophers' and their observations in the Tokaj Mountains (NE Hungary) in the late 18th century (Johann Ehrenreich von Fichtel, Robert Townson and Jens Esmark). Bull of Geol Soc Hung 133(1): $125-140$

Rózsa P, Szöőr GY, Elekes Z, Gratuze B, Uzonyi I, Kiss Z (2006) Comparative geochemical studies of obsidian samples from various localities. Acta Geol Hung 49(1):73-87

Ruban DA (2010) Quantification of geodiversity and its loss. Proc Geol Assoc 121(3):326-333

Ruban DA (2016) Comment on "Geotourist values of loess geoheritage within the planned Geopark Małopolska Vistula River Gap, Poland" by J. Warowna et al. [Quaternary International, in press]. Quaternary International (in press)

Schafarzik F (1904) A magyar korona országai területén létező kőbányák részletes ismertetése Magyar Állami Földtani Intézet, p 413

Seghedi I, Downes H (2011) Geochemistry and tectonic development of Cenozoic magmatism in the Carpathian-Pannonian region. Gondwana Res 20:655-672

Seghedi I, Downes H, Szakacs A, Mason PRD, Thirlwall MF, Rosu E, Pecskay Z, Marton E, Panaiotu C (2004) Neogene-quaternary magmatism and geodynamics in the Carpathian-Pannonian region: a synthesis. Lithos 72:117-146

Seghedi I, Downes H, Harangi S, Mason PRD, Pecskay Z (2005) Geochemical response of magmas to Neogene-quaternary continental collision in the Carpathian-Pannonian region: a review. Tectonophysics 410:485-499

Singer BS, Andersen NL, Le Mével H, Feigl KL, DeMets C, Tikoff B, Thurber CH, Jicha BR, Cardona C, Córdova L, Gil F, Unsworth MJ, Williams-Jones G, Miller C, Fierstein J, Hildreth W, Vazquez J (2014) Dynamics of a large, restless, rhyolitic magma system at Laguna del Maule, southern Andes, Chile. GSA Today 24:4-10

Szabó J (1866) Tokaj-Hegyalja és környékének földtani viszonyai Mathematikai és Természettudományi Közlemények. 4:226-303

Szabó J (1894) Típuskeveredés a Tokaj-hegyalján. - In: Típuskeveredések a dunai trachytcsoportban. Földtani Közlöny 24: 171-172

Szabó J, Török S (1867) Album of Tokay-Hegyalja, vinicultural society by Tokay-Hegyalja, Pest, p 244

Szepesi J, Ésik Z (2015) Megyer Hill: old millstone quarry. In: Lóczy D (ed) Landscapes and landforms of Hungary Springer Science, pp 227-235

Szepesi J, Ésik Z, Novák TJ, Harangi Sz (2015) Hidden volcanic geoheritage of an UNESCO World Heritage Site, Tokaj Wine Region, Historic Cultural Landscape, Hungary 2nd Volcandpark Conference, Lanzarote Abstract Book, pp 35-36

T Biró K (1984) Distribution of obsidian from the Carpathian sources on central European Palaeolithic and Mesolithic sites. AAC 23:5-42

T Biró K (2002) Advances in the study of early Neolithic lithic materials in Hungary. Antaeus 25:119-168

pingvellir Commission (2004) Pingvellir National Park Management Plan 35, pp 2004-2024

Thouret JC (1999) Volcanic geomorphology - an overview. Earth-Sci Rev 47:95-131

Thouret JC (2004) Hazards and processes on volcanic mountains. Chapter 11 in Owens PO and Slaymaker O (eds.) Mountain geomorphology. Arnold pp 242-273.

Townson R (1797) Travels in Hungary with a short account of Vienna in the year 1793. London 
Geoheritage

Tuzson J (1901) A Tarnóczi kövült fa (Pinus tarnócziensis n. sp.) (Der Fossile Baustamm bei Tarnócz) (Pinus tarnócziensis n. sp.). Termr Füz 24:273-316

Váti KHT (2000) The world heritage documentation for the nomination of the cultural landscape of Tokaji wine region. Hungarian Ministry of Environmental Protection, Budapest, p. 143

Veres M, Gadányi P, Tóth G (2015) Thermal spring cones at the Tihany Peninsula. In: Lóczy D (ed) Landscapes and landforms of Hungary. Springer, pp 71-79

Vujicic MD, Vasiljevic DE, Markovic SB, Hose TA, Lukic T, Hadzic O, Janicevic S (2011) Slankamen villages preliminary geosite assessment model (GAM) and its application on Fruska Gora Mountain, potential geotourism destination of Serbia. Acta Geographica Slovenica 51(2):361-377

Warowna J, Zgłobicki W, Kołodynska-Gawrysiak R, Gajek G, Gawrisiak L, Telecka M (2016) Geotourist values of loess geoheritage within the planned Geopark Malopolska Vistula river gap, Poland. Quaternary International (in press)

Wilson CJN, Houghton BF, McWilliams MO, Lanphere MA, Weaver SD, Briggs RM (1995) Volcanic and structural evolution of Taupo Volcanic Zone, New Zealand: a review. J Volcanol Geotherm Res 68:1-28
Wimbledon WA (2011) Geosites - a mechanism for protection, integrating national and international valuation of heritage sites. Geologia dell'Ambiente, supplemento n. 2/2011:13-25

Wimbledon WA, Benton MJ, Bevins RE, Black GP, Bridgland DR, Cleal CJ, Cooper RG, May VJ (1995) The development of a methodology for the selection of British geological sites for geoconservation: part 1. Mod Geol 20:159-202

Wimbledon WAP, Andersen S, Cleal CJ, Cowie JW, Erikstad L, Gonggrijp GP, Johansson CE, Karis LO, Suominen V (1999) Geological World Heritage: GEOSITES - a global comparative site inventory to enable prioritisation for conservation. Memorie Descrittive della Carta Geologica d'Italia, vol. LIV. pp 45-60

Wood C (2009) World Heritage volcanoes: A thematic study. A global review of volcanic World Heritage properties: present situation, future prospects and management requirements. IUCN World Heritage Studies 8, Gland, Switzerland, pp 61

World Heritage Committee (2002) Decisions adopted by 26th session of the World Heritage Committee, WHC-02/CONF.202/INF.15. pp $61-62$

Zelenka T, Gyarmati P, Kiss J (2012) Paleovolcanic reconstruction in the Tokaj Mountains. Cent Eur Geol 55:49-84 